\title{
Ferrous metallurgy from the Bir Massouda metallurgical precinct at Phoenician and Punic Carthage and the beginning of the North African Iron Age
}

\author{
Brett Kaufman $^{\mathrm{a}^{*}}$, Roald Docter ${ }^{\mathrm{b}}$, Christian Fischer ${ }^{\mathrm{c}}$, Fethi Chelbi ${ }^{\mathrm{d}}$, Boutheina Maraoui Telmini ${ }^{\mathrm{e}}$
}

a) Joukowsky Institute for Archaeology and the Ancient World, Brown University, Rhode Island Hall, Box 1837, Providence, RI, 02912, USA

b) Department of Archaeology, Ghent University, Ghent (BE), Sint-Pietersnieuwstraat 35, B9000 Ghent, Belgium

c) Department of Materials Science and Engineering, University of California, Los Angeles (UCLA), 410 Westwood Plaza, Los Angeles, CA, 90095 1595, USA

d) Institut National du Patrimoine, 4 Place du château, TN-1008, Tunis, Tunisia

e) Faculté des Sciences Humaines et Sociales de Tunis, University of Tunis, Boulevard du 9 Avril 1938, Tunis, Tunisia

*Corresponding author, Tel: 312-505-0170; email: brett_kaufman@brown.edu

Excavations of the Phoenician and Punic layers at the site of Bir Massouda in Carthage have provided evidence for ferrous metallurgical activity spanning several centuries.

Archaeometallurgical analyses of slagged tuyères, slag, and alloys using optical microscopy, portable $\mathrm{x}$-ray fluorescence spectroscopy ( $\mathrm{pXRF}$ ), and variable pressure scanning electron microscopy coupled with energy dispersive $x$-ray spectroscopy (VPSEM-EDS) show that Carthaginian smiths were conducting primary smithing and forging of wrought iron and steel. Although the majority of slag specimens are remnant from ferrous production, a few select finds are from bronze recycling. The corpus represents the earliest known ferrous metallurgy in North Africa. As a Phoenician colony then later as an independent imperial center, Carthage specialized in centrally organized ferrous technology at the fringes of the settlement in areas such as Bir Massouda and the Byrsa Hill from before 700 to 146 BC.

Keywords: Archaeometallurgy; Slag; Tuyères; North Africa; pXRF; SEM-EDS

\section{Introduction}

The earliest current evidence of ferrous metallurgical production in North Africa was recovered through excavations at the site of Bir Massouda within the urban center of Carthage (Figs. 1 and 2). The established chronology previous to the research presented here is that metallurgical production at Carthage was only firmly dated from the late $5^{\text {th }}-3^{\text {rd }}$ centuries BC on the southern slope of the Byrsa Hill (Fig 3; Niemeyer 2001; Lancel 1982, 1981, 1979), with some possible earlier scattered finds (Keesmann 2001), skewing our understanding of early North African iron metallurgy and Phoenician contact. Beyond the Byrsa and Bir Massouda areas, smaller-scale, localized metallurgical activity is also found throughout pockets of the ancient city. There is evidence of a singular later 3rd century BC workshop just northwest of the Tophet. Occasional iron smelting and smithing was practiced on the west side of the channel in the area of the commercial harbor (east of the Tophet) dating to ca. 400-350 BC, with some contemporary material coming from the Ilôt de l'Amirauté in the military harbor (northeast of the Tophet), as well as slags and tuyères from a 7th century BC dump at rue Ibn Chabâat (Chelbi 2004; Essaadi 
1995a, 1995b; Hurst and Stager 1978). However, Tylecote (1982) dates the channel tuyères to ca. 350-250 BC based on comparisons with the Byrsa examples.

Some material culture remains associated with metallurgy from Magon's Quarter, dumped into a Magonid context in antiquity but that may be residual from Early Punic layers, have been analyzed by Keesmann (2001, 1994; Rakob 1989). Limited metallurgical activity in Bir Massouda, including a coin mould (221-210 BC) and four slagged tuyères, dated to the $3^{\text {rd }}$ $2^{\text {nd }}$ centuries $\mathrm{BC}$ before the destruction of the city, are either residual from earlier periods or indicative of small-scale metallurgical activities within the urban center (Frey-Kupper 2008; Docter 2005). The coin mould may have come from the vicinity of a nearby public space such as the Agora/Maqom which has yet to be identified archaeologically (Maraoui Telmini et al. 2014; Maraoui Telmini, Chelbi, and Docter 2014). The corpus from Bir Massouda is the earliest known ferrous metallurgy from North Africa. Previously unpublished slag pieces from domestic contexts underneath the Decumanus Maximus published here also help to supplement the picture of early metallurgy at the Carthaginian capital.

\section{Phoenician Iron Metallurgy and Political Economy}

In order to place the role of North African metallurgical data from Carthage in its broader Mediterranean and Near Eastern contexts, it is worthwhile to review the interactions and models for material exchange between Tyrians and their Tartessian, Andalusian, Sardinian, Judean, and North African counterparts. The Phoenicians were primarily interested in extracting silver resources from the Iberian Peninsula to import back to Neo-Assyria and other later Mesopotamian Empires which were hungry for luxury items such as precious metals, ivory, and purple dye (Frankenstein 1979; see Aubet 2008 for a critique of this paradigm; Aubet Semmler 2002a-d). In exchange for provision of mineral resources and maritime skills, the Mesopotamian states granted political autonomy to Tyre (Katzenstein 1997, 163, 165, 166, 209-210, 256). To maintain this arrangement, Tyre established a network of colonies such as Carthage that in turn were themselves tasked with providing tribute back to Tyre.

Early Phoenician colonial activities were centrally planned around a strategy of grafting Tyrian economic demand onto previously established trade networks, in what can be called a cooperative mercantile economic system that encouraged surplus production for export (Morehart and De Lucia 2015). For example, the Tyrians were able to negotiate commercial relationships with local tribes to access the mineral wealth of the Iberian Peninsula. In the 10th and 9th centuries BC, so-called "Orientalizing" influences in the Central and Western Mediterranean are usually referred to as "protocolonization" or "precolonization" initiated by Phoenician merchants plying foreign waters searching for mineral resources to exploit (Johnston 2013; Valério et al. 2013; Valério et al. 2010; Dietler 2009; van Dommelen 1998). The earliest evidence of Phoenician settlers in the West comes from Huelva and the region of Tartessos by the 9th century BC, if not earlier (Aubet 2008, 247; Canales, Serrano, and Llompart 2008, 648). The new international economy was based on shared incentives and is characterized archaeologically by an increase in metallurgical production and warehousing.

Evidence is widespread for iron production at other Phoenician colonies such as those in the Iberian Peninsula that are contemporary with their indigenous silver producing counterparts, coming from such settlements as Abdera, Cabecico de Parra, Morro de Mezquitilla, Cerro del Peñón, La Fonteta, Sa Caleta, and Santa Olaia (Renzi, Montero-Ruiz, and Bode 2009; Neville 2007, 136; Ortega-Feliu et al. 2007; Renzi and Rovira 2007; Salamanca et al. 2006; Kassianidou 
2003; Jurado 2002; Niemeyer 2002; Ramón 2002; Kassianidou 1992; Keesmann and Hellermann 1989). At Tartessian sites such as Cabezo de San Pedro, San Bartolomé, Huelva, and perhaps Almonte, silver working installations can be found that date just before the arrival of Phoenicians, with accelerated developments following colonial contact (Ruiz Mata 2002, 265). Whereas most Phoenician sites on the Iberian Peninsula show evidence of at least localized, small-scale iron production, the native tribes were unquestionably the entity behind the actual mining and smelting of silver. Indigenous sites of the $8^{\text {th }}$ and $7^{\text {th }}$ centuries BC such as Cerro Salomón, Quebrantahuesos, and Corta Lago have revealed extensive evidence of cupellation (Neville 2007: 140-141). The latter site may have begun producing silver in the pre-Phoenician Late Bronze Age. Relationships were forged with Andalusian and Tartessian chieftains who were able to increase their own status by the acquisition of finished Phoenician products in exchange for silver, including iron which was unknown to them before Orientalizing contact in the Final Bronze Age or no later than the $8^{\text {th }}$ century BC (Dietler 2010; Dietler and López-Ruiz 2009). In the Levantine homeland, Phoenicians adopted ferrous technology for agricultural and military applications by at least the $10^{\text {th }}-9^{\text {th }}$ centuries BC (Mazar 2004; Dayagi-Mendels 2002; Gal and Alexandre 2000), and were able to use this technology as a surplus trade good to create amicable economic relations abroad. Horizontal cultural transmission between Phoenician and indigenous populations are attested for other knowledge types such as architectural technologies which may also have been traded, such as in the example of an ashlar retaining wall engineered to prevent erosion from rainfall found in the Tartessian village of San Pedro dating to ca. 800 BC. This wall finds a parallel in Tyre which dates to ca. 850 BC (Ruiz Mata 2002, 267-9). The Tyrian state also may have signified their good intentions and a mutualistic commercial relationship to the Tartessians in the western part of the Peninsula by the establishment of a temple at Gadir honoring Melqart, which would serve to symbolize the long-term economic commitment of the Tyrian officials to their local counterparts in addition to being a place where grievances and claims could be officially brought forth (Fentress 2007; Aubet Semmler 2002b, 230; and cf. Shaw 1989 for possible evidence of this type of interaction at 9th-8th centuries BC Kommos, Crete). Native cultures adopted or imported Phoenician cultural elements, for example at Castro dos Ratinhos including rectilinear dwellings, red slip pottery, iron, and ivory (Valério et al. 2010, 1812).

The precipitation in the local consumption of iron "prestige-objects" stands in contrast to the lack of iron production in the Iberian Peninsula during the precolonial phase. In other words, Phoenicians and indigenous populations traded iron goods, but only the former produced them until the technology itself was transmitted as opposed to just the objects. Ferrous technology and implements are well-attested at the Phoenician settlements of Morro de Mezquitilla and Cerro del Villar during the 8th century BC (Sanmartí 2009, 55; Niemeyer 2001). At Morro and Tejada, changes in smelting technology are apparent following Phoenician contact, with iron content increasing in copper alloys compared to all previous periods studied (Craddock and Meeks 1987, 190, table 1). In Portugal, copper, tin, and gold made their way from the hinterland mines to the coast. Presence of Near Eastern populations is inferred at the Beira Alta region of Portugal, where fragments of a small curved iron knife were found, as well as at Almada with additional curved iron knives. These strata have been respectively radiocarbon dated (calibrated) from 1310-1009 cal BC (two sigma), and 994-783 cal BC (two sigma) (Margarida Arruda 2009, 121), providing early evidence for exchange. Adoption of Phoenician technological practices was selective and gradual as indigenous Portuguese communities integrated their own well-developed non-ferrous metallurgical traditions to the Phoenician political economy (Valério et al. 2013; 
Valério et al. 2010). It has been suggested that the demand for iron in the Iberian Peninsula gradually accelerated due to the removal of scrap bronze in commercial circulation by Phoenicians throughout the Iron Age, further cementing the need for indigenous groups to rely on new Phoenician imports (Aubet Semmler 2002a).

The Carthage Survey established a few valuable facts about the Carthaginian hinterlands within a $30 \mathrm{~km}$ radius of the city (Greene 1986). In the 7th-5th centuries BC, sites with Punic finds are scarce, numbering only seven. Their existence was dependent on the goodwill of the Libyans. Prior to later periods (4th century BC - 9 sites, $3 \mathrm{rd} / 2 \mathrm{nd}$ centuries BC 50 sites) that showed Punic settlements investing in the development of their own agricultural surplus, the Early Punic population relied on Libyan agricultural production, or on imported cereals. Few excavations have focused on these contemporary Libyan settlements, but targeted research at the inland settlement of Althiburos has provided a case study for early CarthaginianNumidian interactions in the contact period. Some ferrous slag was found at Althiburos in the $9^{\text {th }}$ or $8^{\text {th }}$ centuries BC, indicating contacts between the autochthonous population and Phoenician settlers including ferrous technological transmission (Sanmartí et al. 2012; Kallala and Sanmartí 2011; Kallala et al. 2010). A level dated to the end of the $9^{\text {th }}$ century BC at Althiburos provided one shapeless iron implement. The beginning of the 6th century BC witnesses accelerating Punic influence, including perhaps actual Carthaginian settlers as evidenced by a Punic cistern, and even a defensive wall by the 3rd century BC (Sanmartí et al. 2012, 33).

The model of Phoenicians exchanging their technological knowledge for food is attested historically in the Levant. Food shortages are one of the key factors in explaining the alliance between Tyrian King Hiram and Judean King Solomon, in which the former sent metalworkers, masons, and raw materials to Jerusalem to construct the palace and temple, and in return received twenty cities in northern Israel which were supposed to (but fell short) of bolstering agricultural production (I Kings 9:11).

Iron implements from as far afield as the Portuguese Atlantic coast (Margarida Arruda 2009; Aubet Semmler 2002a, 104), to bronze artifacts from the Sardinian S. Antioco and Phoenician style brooches on the eastern coast of Sicily (van Dommelen 1998, 75) demonstrate that the tribute system of metal supply to the Neo-Assyrians was not unidirectional toward Mesopotamia. Local elites in the indigenous areas desired, acquired, and consumed Phoenician metal craft as well as the Neo-Assyrians. It is therefore necessary to understand that the Phoenician and Neo-Assyrian supply of base and precious metals was predicated on the corollary demand of the indigenous groups for Phoenician ferrous alloys and other technologies.

Excavations at Bir Massouda were undertaken to provide a fuller picture of the early urban development of Carthage, a Tyrian colony founded at the strategic maritime crossroads between the Eastern and Western Mediterranean. A metallurgical horizon dating just after the establishment of the colony was recovered (end of the $8^{\text {th }}$ through $5^{\text {th }}$ centuries BC), in addition to later residential and public features $\left(4^{\text {th }}\right.$ through $2^{\text {nd }}$ centuries BC). Archaeometric analyses were conducted on the remains of the metallurgical material culture to classify the type and scale of production, and to discern how these goods were used in the Tyrian commercial network and later independent Carthaginian polity.

\section{Materials and Methods}

\subsection{Archaeological context}


An area dedicated to metallurgical production of a minimum extent of 1,500 $\mathrm{m}^{2}$ was excavated at Phoenician and Punic Carthage (ca. 800-146 BC) between 2000 and 2005 known as Bir Massouda (alternately spelled Messaouda; Table 1, Figs. 1 and 2; Docter et al. 2006; see also Docter et al. 2003; Docter 2002-2003). The metallurgical horizon was situated over an earlier Early Punic cemetery. Carthaginian smiths undertook ferrous metallurgy beginning as early as the $8^{\text {th }}$ century BC, but the bulk of production at Bir Massouda dates from 650-500 BC, with production tapering off throughout the $5^{\text {th }}$ century BC (Bechtold 2010; Docter et al. 2008; Docter et al. 2005). By around 425-400 BC or slightly later the area was transformed into a residential quarter, and metallurgical activity was transferred to the south slopes of the Byrsa Hill where it also took the place of an Early Punic cemetery. This new Byrsa metallurgical zone remained in existence from the late $5^{\text {th }}$ to the end of the $3^{\text {rd }}$ centuries BC (Lancel 1995, 1985). The two zones together are the only two areas with known evidence of long-term, centralized metallurgical industry at Carthage (Fig. 3). The remains published here are the entirety of ferrous metallurgical material culture excavated from undisturbed and well-dated contexts; much material from disturbed archaeological contexts, or from trench cleaning activities is not taken into account.

\subsection{Samples}

One trench at Bir Massouda revealed extensive metallurgical material culture in the form of furnace debris, with other finds related to metallurgy in contemporary secondary contexts such as streets, outdoor surfaces, fills, and leveling layers. The corpus is comprised of slagged tuyères, slag, ferrous and non-ferrous alloys, as well as other infrastructure such as a basalt anvil with ferrous residue (Kaufman 2014, Appendix IV).

\subsubsection{Slagged tuyères}

There are 54 slagged tuyères in the corpus which range from nearly complete slagged tips to heavily damaged fragments which still maintain morphology of a tuyère as discerned by preserved barrels (Figs. 4 and 5), with hundreds more tuyère fragments recovered. Of the welldated specimens, 36 date from ca. 800-500 BC (21 of these date specifically from ca. 700-500 BC); 14 are broadly dated from ca. 800-400. No slagged tuyères are attested from ca. 400-200 BC; four date from ca. 200-146 BC (Fig. 6). These latter four slagged tuyères dating to the last half century of Punic Carthage (200-146 BC) are likely residual from earlier activities, and less likely to represent a resumption of small-scale, localized metallurgical production.

\subsubsection{Slag}

Several kilograms of slag ranging from small, pea-sized loose pieces to hand-sized slag cakes were also recovered from excavations at Bir Massouda. Samples selected for analysis were those that could be dated definitively within distinct categories in order to aid interpretations based on clear chronologies and which were confirmed metallographically as slag (Fig. 7, n=11 from 800$600 \mathrm{BC}, \mathrm{n}=2$ from 550-475, and $\mathrm{n}=1$ from 330-300 BC). Three additional pieces of contemporary slag were excavated from Punic domestic contexts under the Roman Decumanus Maximus by a separate team from Hamburg University (dating 700-550 BC; Niemeyer et al. 2007; cf. Fig. 1), and are published here for the first time. 33 slag samples of broad chronology 
$\left(8^{\text {th }}-2^{\text {nd }}\right.$ centuries BC) are almost certainly slag based on their morphology judged through ocular observation (Girbal 2013; Soulignac and Serneels 2013).

The morphology and coloration of the slag assemblages are highly diverse. Some pieces look like simple iron corrosion which upon microscopic investigation were revealed as slag (Fig. 8i), while others were smooth and brown-black and maintaining a vitreous form from the original processing (Fig. 8ii), while still others were black (Fig. 8iii). Some were slag cakes large enough to hold with both hands (Fig. 8iv) while others were smaller slag droplets. The consistent use of tuyères over many centuries in a circumscribed area would have resulted in a greater tonnage of slag than recovered, and it is likely that this was dumped elsewhere although no slag heaps at Carthage have yet been found.

\subsubsection{Ferrous alloys}

Four ferrous alloys were recovered from Bir Massouda, which included two complete nails (one dated from 550-330 and the other from 300-146 BC; Kaufman 2014 Appendix IIIE), and two fragments that were sampled for archaeometallurgical analysis and discussed in the Results and Discussion section below (one dated 650-530 and the other 550-500 BC). Two other specimens may be identified microstructurally as bloomery slag.

\subsection{Analytical techniques}

Materials from the Bir Massouda assemblage were characterized to examine their compositional and microstructural traits. This allowed for identification and comparison of the various technological practices and choices made by the city founders. The analyses were conducted using pXRF, SEM-EDS, and metallographic light optical microscopy.

\subsubsection{Portable X-ray fluorescence spectroscopy ( $p X R F)$}

PXRF was used for qualitative analysis of the slagged tuyères and loose slag. This technique provided rapid, non-destructive, and minimally invasive analysis which served simultaneously to characterize the metal produced and to identify anomalies. XRF is a useful tool for determining bulk composition of these materials, and depending on the elements and calibration procedures can range from quantitative determination of elemental composition to qualitative determination that an element is simply present in a sample. The analyses here are to be considered in the latter, qualitative category in nominal scale. Slag and slagged layers on tuyères are extremely heterogeneous materials, and the metal and ceramic phases often form a continuum. Therefore the compositions presented here generated by $\mathrm{pXRF}$ are not meant to be absolute wt $\%$ averages of the slags, but serve rather to indicate qualitatively ferrous versus non-ferrous phases. The concentrations listed are not absolute measurements, and compositional values cannot be manipulated to represent quantifiable differences between artifacts or elements.

Samples of slagged tuyères were gently brushed to clean and expose the surfaces to be analyzed without any further preparation, often leaving some depositional accretions. For many of them, the surface corresponded to a break with a heterogeneous texture and irregular geometry which are factors known to affect the accuracy of the measurements. Although it is preferential to analyze slag in a flat cross section, many of the slagged tuyères are complete vessels so a noninvasive method was preferred. Whenever possible, several spots were analyzed and averaged, 
but often data could be collected only from one spot, and in some cases with a $3 \mathrm{~mm}$ collimation, due to sample size limitations. In all but a few cases, the instrument was set on an upright tripod and the samples were rested on a stable platform for analysis.

Elemental analysis was conducted using a Thermo Niton XL3t GOLDD+ handheld XRF equipped with a silver anode tube and a large silicon drift detector (SDD) operating at a maximum voltage of $50 \mathrm{kV}$ and current of $200 \mu \mathrm{A}$ with a resolution better than $160 \mathrm{eV}$ and producing an average spot diameter of about $8 \mathrm{~mm}$. Slag and slagged ceramic samples were analyzed in "Mining" mode which uses fundamental parameters calibration iterative algorithm and manufacturer-set internal calibrations to convert X-ray counts into concentrations. Settings for the slagged tuyères and slag was the "Mining $\mathrm{Cu}-\mathrm{Zn}$ " mode, 120 seconds duration, divided into four parameters of 30 seconds each for detection of elements (main, high, low, light). The results are reported in $\mathrm{wt} \%$.

\subsubsection{Metallography}

Metallographic polarized light microscopy was conducted with a Nikon Epiphot-TME metallographic microscope, as well as a Leica DMRM in order to identify the microstructures of both slags and alloys and corrosion products. Samples were mounted in a two-part epoxy resin, ground with 240 then 600 PSA backed grit, followed by polishing with monocrystalline diamond suspension and/or non-crystallizing colloidal silica suspension of $6 \mu \mathrm{m}$, then finished with $1 \mu \mathrm{m}$ and/or $0.02 \mu \mathrm{m}$. Mostly optical light was used, but for some of the micrographs differential interference contrast (DIC) and/or a red compensator plate was used in order to increase the depth contrast of the image, as well as polarization and dark field settings. Settings were adjusted appropriately in order to capture specific microstructural features that were relevant to the research. Micrographs were mostly taken with a 14 MP eyepiece UCMOS series microscope digital camera, but also in some cases with a Nikon digital camera D3000.

\subsubsection{Variable pressure scanning electron microscopy (VPSEM) and energy dispersive X-ray spectroscopy (EDS)}

VPSEM-EDS analysis of selected slag and alloy materials was conducted on mounted samples in order to attain additional compositional and microstructural resolution of the phases. VPSEMEDS was performed on selected samples of slag and slagged tuyères. EDS spots were taken to record the compositions of hammerscales and calcium-rich matrix, slag phases, and charcoal fuel phases. The instrument is a FEI NovaTM NanoSEM 230 SEM with field emission gun (FEG) and variable pressure capabilities, equipped with a Thermo Scientific NORAN System 7 X-ray EDS. A gaseous analytical detector (GAD) in variable pressure was used for the detection of backscattered electrons (BSE), providing images with compositional contrast. Accelerating voltage was kept to $15 \mathrm{keV}$, chamber pressure was set at $50 \mathrm{mPa}$, and working distance around 8 $\mathrm{mm}$.

\subsection{Standards}

One iron ore (NIST 692), one slag standard (BCS 382/1), and two bronze standards used in the Getty "Round Robin" were analyzed by both pXRF and VPSEM-EDS in order to evaluate instrument capabilities in the context of our study, using the instrument's "Mining" mode (Table 
2; following protocol of Heginbotham et al. 2010). The bronze standards were employed in order to confirm the presence of tin, copper, and lead that were recorded by the pXRF in the two nonferrous slagged tuyère specimens (1112 38082 and 1121 17470). For $\mathrm{pXRF}$, the iron ore and slag standards were analyzed over two acquisitions averaged for each standard in powder form. For EDS, analysis of the pelletized iron and slag standards was conducted through averaging the compositional results in wt $\%$ from five areas at x 1500 magnification totaling an area of 0.042 $\mathrm{mm}^{2}$ per sample.

\section{Results and Discussion}

\subsection{Smithing and smelting of wrought iron and steel}

Archaeometallurgical results yielded a picture of early metallurgical practices at Carthage. Both direct and indirect evidence for the production of wrought iron and steel was found in the Bir Massouda corpus. Although some evidence indicates smelting, the practices at Bir Massouda align more with primary smithing of blooms and secondary smithing into semi-finished (like spitzbarren ingots) or finished products (Wolff 1986, 181-2; Tylecote 1982, 269). It is possible that local smelting occurred closer to iron ore and fuel sources at sites that have yet to be identified. Of the 54 slagged tuyère slag phases analyzed, 52 were ferrous and two were nonferrous as determined by pXRF (Table 3). Of the slag specimens, all 17 were ferrous (Table 4). This case study illustrates why systematic pXRF on large datasets is an effective way to parse out anomalies (in this case the non-ferrous slagged tuyères) in an otherwise seemingly homogeneous taxon of data.

Of all the ferrous metallurgical debris, only four ferrous alloys were recovered, providing evidence that Bir Massouda is a production rather than exclusively a consumption site. These were two iron nails (one dating to the Middle Punic and one to the and Late Punic eras) and two corroded ferrous objects. These latter two objects date to the Early Punic period and were mounted for analysis. The cross section of one, 446049172 (800-530 BC; Kaufman 2014, Appendix III21) showed that contained within the corrosion is a well-preserved shaft of a nail or hook. The object was thoroughly corroded with no alloy phases identified. On the other hand, object 1246 (550-500 BC), also maintaining a rectangular form, contained multiple phases of both metallic iron and mineralized pearlite, or corroded steel (Fig. 9).

Some of the slagged tuyère slag phases were smaller than the pXRF beam diameter, and in such a case the fluorescence produced, particularly in light elements, will be absorbed by the material and then the air. It is therefore most likely that attenuation was a major factor in the results outcome, and also accounts for why the total oxide values are below $100 \%$. Specifically, the factors affecting the total values are that magnesium was not detected, an underestimation of aluminum and silicon due to the partial absorption of the emitted fluorescence by air in relation to the low energy of this radiation, the chemical and geometrical heterogeneity of the surface/subsurface in comparison to the bulk, and possibly the small size of the sample. Tables 3 and 4 are ordered by chronological period and archaeological locus and report the raw compositional data of the $\mathrm{pXRF}$.

All preserved tuyères at Bir Massouda were double barreled with toggled, parallel holes running down the entirety of the nozzle from air source to furnace (Figs. 3 and 4). Tuyères were used repeatedly as the smiths poked holes through the molten slag in order to keep the airways clear. Of the 36 slagged tuyères which date to the Early Punic period, as mentioned above only 
two can be considered non-ferrous (Fig. 10) and the rest as ferrous. The non-ferrous phases in the Bir Massouda slags contain both copper and tin, indicating melting or recycling activities. The plant-like shoots in Figure 10ii are comprised of tin and copper, either delafossite with magnetite spinels or cassiterite (cf. Hauptmann 2014 figure 5.5c; Taskinen et al. 2013; Radivojević et al. 2010 fig. 8; Bachmann 1982).

Generally speaking, slag inclusions are in local equilibria with the surrounding metal. The presence of wüstite rich inclusions occurs most frequently with ferrite and wrought iron, whereas the absence of iron oxides but the abundance of the fayalite and glassy, or just glassy phases is associated with pearlite - the key ingredient of "natural steels" (Buchwald and Wivel 1998, 83, 94; Craddock 1995, 236). While keeping in mind that the data here are not slag inclusions in an alloy matrix but actual slag, these qualitative principles can still be considered relevant in the identification of the alloy products that may have resulted from these slag phases.

Great variation in wüstite content is expected even within a single slag specimen, resulting from the degree of reduction versus oxidation of free iron oxides $(\mathrm{FeO})$. This occurs in both smelting and smithing activities, so wüstite content alone is not sufficient to identify smelting versus smithing slags. The methods employed in this paper are unable to differentiate between iron oxidation states, which is necessary for conclusive identification between magnetite, hematite, and often primary wüstite phases. However, microstructural determinations often provide helpful information, such as in the cases of secondary wüstite and general determination of olivine/fayalite. Most iron oxide phases in the Bir Massouda slagged tuyères and loose slag are primary or secondary wüstite phases — and perhaps some hematite or magnetite —embedded in a glassy matrix often with metallic iron phases or non-ferrous ore "relict" impurities (Hauptmann 2014, 101). In tandem, there are several slags that display purely glassy or olivine/fayalite phases sometimes in crystalline formation, primary and secondary wüstite that could be common to both smelting or smithing slags, and hammerscale that is the byproduct of smithing and forging (Figs. 11-13).

A thick layer of hammerscales was found capping parts of the metallurgical area, suggesting that secondary smithing or forging activities were prevalent (Docter et al. 2003, 44). In secondary smithing, large amounts of metal are lost to hammering in the form of scales and prills, some of which become trapped in slag. Hammerscales form when the iron bloom or metal is continually hot worked. Iron-rich oxides, as well as impurities such as slag, tend to be hammered off (Allen 1986). Two oxidized iron hammerscales can be seen in slag specimen 8339 38255A in Figure 13 embedded in a calcium-rich matrix, providing a lens into a non-slag furnace environment with possible evidence of fluxing (due to the high calcium content and abundance of murex shell remains found among the metallurgical installation) and forging or secondary smithing (Table 5, see also the shell in Fig. 8i).

As mentioned above, 17 individual slag specimens not attached to tuyères were mounted and polished for analysis, as it was possible to separate these into distinct temporal categories (Table 4). These loose slags are generally characterized by an abundance of secondary wüstite and fayalite phases. Still, composition and morphology can also change based upon the location of the slag relative to the bloom (Blakelock et al. 2009, 1745). In order to empirically determine the relative proportions of steel versus wrought iron within this or any assemblage, more quantitative analysis would have to be conducted on large quantities of the slag. One of the slag pieces from the Early Punic domestic context under the Decumanus Maximus, specimen KA91/496-17, was sealed in the primary destruction layer of a room and is a ferrous slag likely resultant from the production of pearlite due to the exclusively fayalitic and glassy phases (Fig. 
12). Taking all the data together, the mineralized pearlite from iron alloy 1246 and the abundant fayalite phases in the slag specimens represent evidence of steel metallurgy.

No ores were recovered from the site, which would suggest a preclusion or minimization of smelting activities at Bir Massouda. Nonetheless, the quantity and types of slag (including several large slag cakes akin to those recovered from smelting experiments, cf. Girbal 2013) likely preclude forging operations alone. It is likely that purification through forging of fairly dirty blooms that were brought into the Bir Massouda zone was the major activity (Allen 1986), with some smelting as well. As for smelting evidence, Figure $14 \mathrm{i}$ shows two eutectics in the $\mathrm{FeO} / \mathrm{SiO}_{2}$ system with adjacent secondary wüstite (larger yellow globules) and fayalite phases (laths by the scale bar), which are found in smelting tap slag and blooms (for comparanda cf. Phelps 2013, fig. 2; Bachmann 1982: 32-33, Plate XXIVb and c). Slag adhering to the bloom tends to be depleted in $\mathrm{FeO}$ relative to the average bloomery slag (including such varieties as furnace slag and tap slag) derived from the same iron production system or smelt, a characteristic that many of the Bir Massouda slags possess with widespread fayalite and glassy phases (artifacts 250445012 and 1246a in Fig. 14; Blakelock et al. 2009, 1748). 1246a showed multiple zones with wüstite (cf. Smith 2013, figure 9 for comparandum for slag from a "nascent" bloom), as well as iron oxide and glass slag phases. The microstructure and composition of this zone indicates a semi-finished product between slag and metal that could have been formed during either smelting or smithing episodes (Figure 14ii, Table 5).

Specimen 1246a also yielded mineralized timber grains, providing evidence for the use of arboreal fuel sources. The exploitation of timber fuel is illustrated by the deformed wood anatomy represented by a mineralized arboreal cellular structure which pseudomorphed into the iron phases (for comparanda of fossilized organics and charcoal in slag cf. Valério et al. 2013 fig. 7; Radivojević et al. 2010 fig. 6; Schmidt 1997 fig. 6.20). A steady fuel source was always a concern for smiths, and 1246a indicates that timber fuel was used at Carthage dating 550-500 BC (Fig. 14iii, 14iv shows black organic cells and iron-mineralized white cells, Table 5). Exact identification of the tree species was not possible due to the warped morphology of the cells induced by the heat of the furnace.

\subsection{Spatial organization of industrial and household production}

The ratio of ferrous to non-ferrous slagged tuyères at Early-Middle Punic Bir Massouda is 24:1 $(n=48: 2)$, and this can be considered a proxy for the types of metals produced in the precinct: iron and steel alloys made up around $96 \%$ of the metal produced from 800-400 BC at Bir Massouda. This would be expected if Carthage were close to major ore deposits such as seen in the roughly contemporary iron smelting at Tell-Hammeh (Blakelock et al. 2009; Veldhuijzen and Rehren 2007; Veldhuijzen and Rehren 2006). But there is no substantial evidence of early Carthaginian exploitation of local mines (cf. Wolff 1986: 182-183 for a discussion). Although only minimal archaeometallurgical investigation has been conducted on other slags and tuyères from the slopes of the Byrsa and other sites around Carthage, Tylecote (1982:272-273) reports that they are nearly all the result of iron smithing as opposed to smelting, at times with "the odd particle of copper-base alloy". This pattern of nearly exclusive iron production with limited bronze recycling is also borne out at Bir Massouda, meaning that wrought iron and steel production was a specialty of the early colony.

As mentioned above, 33 specimens were determined to be slag but broadly dated to the Early Punic period. 24 of these specimens date to the period 800-500 BC, so they are useful in 
understanding the intensification of centrally organized production versus household production before the $5^{\text {th }}$ century BC. Taking into account only the 11 specimens confirmed metallographically as slag (Table 4), the ratio of household slag under the Decumanus Maximus (ca. 700-550 BC) to the production facility at Bir Massouda (ca. 800-600 BC) is 3:11. When the excluded 24 specimens from $800-500 \mathrm{BC}$ are included, the ratio becomes 3:35. This shows that centrally-organized industrial production was between four to twelve times greater than household production in Early Punic Carthage (Fig. 7). The amount of centrally organized slag production exceeds the amount of slag produced in domestic contexts, indicating state-level or centralized organization of surplus iron commodities.

\section{Conclusions}

The ability to produce wrought iron and steel at the Carthaginian capital-activities ranging from before 700-146 BC at Bir Massouda and the slopes of the Byrsa Hill—-benefited the Carthaginians through possessing specialization of a technology that was a valuable trade good, a strategic asset for urban growth, and that enabled agricultural and military development. Despite the absence of iron ores recovered from excavations, other evidence points toward some smelting along with confirmed primary and secondary smithing of blooms into wrought iron and steel. Ferrous production began in the $8^{\text {th }}$ century BC and lasted from at least 700/650-400 BC at Bir Massouda, at the Byrsa hill from the late $5^{\text {th }}$ to late $3^{\text {rd }}$ centuries $\mathrm{BC}$, and at decentralized locales across the urban area in the final decades of the city.

Centrally organized industrial production of iron and steel was a major component of the Carthaginian economy for at least 450 years (650-200 BC). Based upon the scale and proportion of iron to bronze slagged tuyères at Bir Massouda (24:1), and the ratio of slag production between domestic and industrial contexts (between 3:11 and 3:35), it is most probable that ferrous metallurgy at Bir Massouda was not geared only toward local consumption but rather surplus production. The surplus could be bartered or provisioned as tribute to Tyre. The iron could then be utilized as Tyre saw fit; paid to Neo-Assyria or Babylonia, traded for as an exotic commodity with indigenous Mediterranean elites for silver, left in Carthage to trade for food with North African groups such as at Althiburos, or used by the Tyrian government or Carthaginian residents in other ways.

The little evidence that exists for the North African contact period indicates that the Phoenicians were dependent on imported cereals and probably traded iron from the workshops in Bir Massouda for foodstuffs in the environs of Cape Bon and further inland. Indigenous North African (i.e. Amazigh, Libyan, Numidian) populations in these locations, which did not possess ferrous metallurgy before Phoenician contact, tolerated and eventually encouraged the presence of Phoenicians due to converging economic interests through the Middle Punic period. Compared to lithic technologies prior to Phoenician contact, using iron tools for agriculture would have greatly improved the Numidian food yield. One of the only excavated Numidian sites during the contact period is at Althiburos, where the earliest iron and slag artifacts date to the Early Punic period and perhaps precolonization contact phase.

As regarding the African context of the Bir Massouda finds, we do not attempt to answer the question over whether the Carthaginian iron industry influenced the trajectory of African ferrous metallurgy south of the Sahara (cf. Killick 2015, 2009; Alpern 2005; Childs and Herbert 2005, 280; Holl 2000, 6-10 for thorough discussions). Still, several centuries of continuous ferrous metallurgy at Bir Massouda with slag specimens dated to the $8^{\text {th }}$ and $7^{\text {th }}$ centuries BC 
represent an early, substantial addition to the archaeometallurgical corpus of the North African Iron Age which for the $8^{\text {th }}$ through $6^{\text {th }}$ centuries BC is otherwise undocumented.

\section{Acknowledgments}

This material is based upon work supported by the National Science Foundation Graduate Research Fellowship under Grant No. DGE-0707424. The authors would like to thank the Tunisian Institut National du Patrimoine for access to the materials. Thanks are due to David Scott, Ioanna Kakoulli, and Sergey Prikhodko for access to analytical instruments, including those of the Molecular and Nano Archaeology Laboratory (MNA) of the Cotsen Institute of Archaeology at UCLA. Sarah Paynter (Historic England) kindly provided the iron and slag standards, and Arlen Heginbotham (Getty Museum) the bronze standards. The excavations on the Bir Massouda site were financed by the UTOPA Foundation (Voorhout/Leiden, the Netherlands). Special thanks go to Hans Koens (Amsterdam) for his first metallurgical observations on the samples and to Babette Bechtold (Graz) for her observations on the chronology of some of the contexts discussed here prior to full publication, as well as to John Marston (Boston University) for providing guidance on the arboreal cell structures.

\section{References}

Allen, J. R. L., 1986, Interpretation of some Romano-British Smithing Slag from Awre in Gloucestershire, Historical Metallurgy, 20, 97-104.

Alpern, Stanley B. 2005. Did They or Didn't They Invent It? Iron in Sub-Saharan Africa. History in Africa 32:41-94.

Aubet, Maria Eugenia. 2008. Political and Economic Implications of the New Phoenician Chronologies. In Beyond the Homeland: Markers in Phoenician Chronology, edited by C. Sagona. LeuvenParis-Dudley, MA: Peeters.

Aubet Semmler, Maria Eugenia. 2002a. Phoenician Trade in the West: Balance and Perspectives. In The Phoenicians in Spain: An Archaeological Review of the Eighth-Sixth Centuries B.C.E., edited by M. R. Bierling. Winona Lake, Indiana: Eisenbrauns.

Aubet Semmler, Maria Eugenia. 2002b. The Phoenician Impact on Tartessos: Spheres of Interaction. In The Phoenicians in Spain: An Archaeological Review of the Eighth-Sixth Centuries B.C.E., edited by M. R. Bierling and S. Gitin. Winona Lake, Indiana: Eisenbrauns.

Aubet Semmler, Maria Eugenia. 2002c. Some Questions Regarding the Tartessian Orientalizing Period. In The Phoenicians in Spain: An Archaeological Review of the Eighth-Sixth Centuries B.C.E., edited by M. R. Bierling. Winona Lake, Indiana: Eisenbrauns.

Aubet Semmler, Maria Eugenia. 2002d. Notes on the Economy of the Phoenician Settlements in Southern Spain. In The Phoenicians in Spain: An Archaeological Review of the Eighth-Sixth Centuries B.C.E., edited by M. R. Bierling. Winona Lake, Indiana: Eisenbrauns.

Bachmann, H. G. 1982. The Identification of Slags from Archaeological Sites, Occasional Publication No. 6. London: Institute of Archaeology.

Bechtold, Babette. 2010. The Pottery Repertoire from Late 6th-Mid 2nd Century BC Carthage: Observations Based on the Bir Messaouda Excavations. Carthage Studies 4:1-81.

Blakelock, Eleanor, Marcos Martinón-Torres, Harald A. Veldhuijzen, and Tim Young. 2009. Slag Inclusions in Iron Objects and the Quest for Provenance: An Experiment and a Case Study. Journal of Archaeological Science 36:1745-1757.

Buchwald, Vagn Fabritius, and Helle Wivel. 1998. Slag Analysis as a Method for the Characterization and Provenancing of Ancient Iron Objects. Materials Characterization 40:73-96. 
Canales, González de, Leonardo Serrano, and Jorge Llompart. 2008. The Emporium of Huelva and Phoenician Chronology: Present and Future Possibilities. In Beyond the Homeland: Markers in Phoenician Chronology, edited by C. Sagona. Leuven-Paris-Dudley, MA.: Peeters.

Charlton, Michael F., Peter Crew, Thilo Rehren, and Stephen J. Shennan. 2013. Measuring Variation in Iron Smelting Slags: an Empirical Evaluation of Group-Identification Procedures. In The World of Iron, edited by J. Humphris and T. Rehren: Archetype.

Chelbi, Fethi. 2004. Tunesische Forschungen in Karthago. In Hannibal ad portas. Stuttgart: Theiss.

Craddock, P. T. 1995. Early Metal Mining and Production. Washington, D.C.: Smithsonian Institution Press.

Craddock, P.T., and N.D. Meeks. 1987. Iron in Ancient Copper. Archaeometry 29 (2):187-204.

Dayagi-Mendels, Michal, ed. 2002. The Akhziv Cemeteries: The Ben-Dor Excavations, 1941-1944, IAA Reports 15. Jerusalem: Israel Antiquities Authority.

Dietler, Michael. 2009. Colonial Encounters in Iberia and the Western Mediterranean: An Exploratory Framework. In Colonial Encounters in Ancient Iberia: Phoenician, Greek, and Indigenous Relations, edited by M. Dietler and C. López-Ruiz. Chicago: University of Chicago Press.

Dietler, Michael. 2010. Archaeologies of Colonialism: Consumption, Entanglement, and Violence in Ancient Mediterranean France. Berkeley: University of California Press.

Dietler, Michael, and Carolina López-Ruiz, eds. 2009. Colonial Encounters in Ancient Iberia: Phoenician, Greek, and Indigenous Relations. Chicago: University of Chicago Press.

Docter, R. F. 2005. Een Spectaculair Einde Carthago: 246-146. Chr. Lampas 38:313-329.

Docter, R. F., Hans Georg Niemeyer, A. J. Nijboer, and H. van der Plicht. 2005. Radiocarbon Dates of Animal Bones in the Earliest Levels of Carthage. In Oriente e Occidente: metodi e discipline a confronto. Riflessioni sulla cronologia dell'età del ferro in Italia, Atti dell'Incontro di studi, Roma, 30-31 ottobre 2003. Mediterranea, 1 (2004), edited by G. Bartoloni and F. Delpino. Pisa: Istituti Editoriali e Poligrafici Internazionali.

Docter, R.F., F. Chelbi, Bouthéina Maraoui Telmini, A.J. Nijboer, J. Van der Plicht, W. Van Neer, K. Mansel, and S. Garsallah. 2008. New Radiocarbon Dates from Carthage: Bridging the Gap between History and Archaeology? In Beyond the Homeland: Markers in Phoenician Chronology, edited by C. Sagona. Leuven, Paris, Dudley: Peeters.

Docter, Roald F. 2002-2003. The Topography of Archaic Carthage: Preliminary Results of Recent Excavations and Some Prospects. TALANTA XXXIV-XXXV:113-133.

Docter, Roald F., Fethi Chelbi, Boutheina Maraoui Telmini, Babette Bechtold, Hans Koens, Karin Schmidt, and Wim Van Neer. 2003. Carthage Bir Massouda - Preliminary Report on the First Bilateral Excavations of Ghent University and the Institut National du Patrimoine (2002-2003). BABesch. 78:43-70.

Docter, Roald F., Fethi Chelbi, Boutheina Maraoui Telmini, Babette Bechtold, Hamden Ben Romdhane, Vanessa Declercq, Tijs De Schacht, Eline Deweirdt, Alain De Wulf, Lamia Fersi, Suzanne FreyKupper, Soumaya Garsallah, Ineke Joosten, Hans Koens, Jalel Mabrouk, Taoufik Redissi, Sihem Roudesli Chebbi, Karen Ryckbosch, Karin Schmidt, Birgit Taverniers, Julie Van Kerckhove, and Lieven Verdonck. 2006. Carthage Bir Massouda: Second Preliminary Report on the Bilateral Excavations of Ghent University and the Institut National du Patrimoine (2003-2004). BABesch 81:37-89.

Essaadi, F. 1995a. 'Recherches sur l'Histoire de l'Archéologie du Fer en Tunisie', Compte Rendu de la Communication Présentée au 3ème Congrès des Études Phéniciennes (Tunis Novembre 1991) REPPAL 9:217-8.

Essaadi, F. 1995b. Recherches sur l'Histoire et l'Archéologie du Fer en Tunisie. In Actes du IIIe Congrès International des Études Phéniciennes et Puniques, Tunis, 11-16 novembre 1991, edited by M. H. Fantar and M. Ghaki: Tunis, Institut National du Patrimoine.

Fentress, Elizabeth. 2007. Where were North African Nundinae Held? In Communities and Connections: Essays in Honour of Barry Cunliffe, edited by C. Gosden. New York: Oxford University Press. 
Frankenstein, S. 1979. The Phoenicians in the Far West: A Function of Neo-Assyrian Imperialism. In Power and Propaganda: A Symposium on Ancient Empires, edited by M. T. Larsen. Copenhagen: Akademisk.

Frey-Kupper, Suzanne. 2008. A Stone-Mould for Producing Carthaginian Bronze Coins of the Second Punic War from Carthage Bir Massaouda. In XVII International Congress of Classical Archaeology, September 22-26 2008. British School in Rome.

Fumadó Ortega, I. 2013. Cartago Fenicio-Púnica. Arqueología de la forma urbana, Madrid.

Gal, Zvi, and Yardenna Alexandre. 2000. Horbat Rosh Zayit: An Iron Age Storage Fort and Village, IAA Reports 8. Jerusalem: Israel Antiquities Authority.

Girbal, B., 2013, Experimenting with Bowl Furnaces, in Accidental and Experimental Archaeometallurgy, D. Dungworth, and R. C. P. Doonan, eds., The Historical Metallurgy Society, Occasional Publication No 7.

Greene, Joseph A. 1986. The Carthaginian Countryside: Archaeological Reconnaisance in the Hinterland of Ancient Carthage. Ph.D. dissertation, University of Chicago, Chicago.

Hauptmann, A. 2014. The Investigation of Archaeometallurgical Slag. In Archaeometallurgy in Global Perspective: Methods and Syntheses, edited by B. W. Roberts and C. P. Thornton. New York: Springer.

Heginbotham, Arlen, Aniko Bezur, Michel Bouchard, Jeffrey M. Davis, Katherine Eremin, James H. Frantz, Lisha Glinsman, Lee-Ann Hayek, Duncan Hook, Vicky Kantarelou, Andreas Germanos Karydas, Lynn Lee, Jennifer Mass, Catherine Matsen, Blythe McCarthy, Molly McGath, Aaron Shugar, Jane Sirois, Dylan Smith, and Robert J. Speakman. 2010. An Evaluation of InterLaboratory Reproducibility for Quantitative XRF of Historic Copper Alloys. Paper read at International Conference on Metal Conservation. Interim Meeting of the International Council of Museums Committee for Conservation, Metal Working Group, at Charleston, SC.

Holl, Augustin F. C. 2000. Metals and Precolonial African Society. In Ancient African Metallurgy, edited by M. S. Bisson, S. T. Childs, P. de Barros and A. F. C. Holl. Walnut Creek, CA: Altamira Press.

Hurst, Henry, and Lawrence E. Stager. 1978. A Metropolitan Landscape: The Late Punic Port of Carthage. World Archaeology 9 (3):334-346.

Johnston, Philip Andrew. 2013. Toward a Systematic Approach to the Study of Phoenician Economic Activity in the Western Mediterranean. In SOMA 2012. Identity and Connectivity: Proceedings of the 16th Symposium on Mediterranean Archaeology, Florence, Italy, 1-3 March 2012. Volume 2, edited by L. Bombardieri, A. D’Agostino, G. Guarducci, V. Orsi and S. Valentini. Oxford: Archaeopress, BAR International Series 2581 (II).

Jurado, Jesús Fernández. 2002. The Tartessian Economy: Mining and Metallurgy. In The Phoenicians in Spain: An Archaeological Review of the Eighth-Sixth Centuries B.C.E., edited by M. R. Bierling. Winona Lake, Indiana: Eisenbrauns.

Kallala, Nabil, Joan Ramon Torres, Joan Sanmartí Grego, M. Carme Belarte, Bouthéina Maraoui Telmini, Thaïs Fadrique, Rafael Jornet i Niella, Daniel López Reyes, Núria Morell Cortés, and Sílvia Valenzuela Lamas. 2010. Sobre los Orígenes de la Civilización Númida y su Relación con la Colonización Fenicia. Mainake XXXII (I):279-299.

Kallala, Nabil, and Joan Sanmartí, eds. 2011. Althiburos I: la fouille dans l'aire du capitole et dans la nécropole méridionale, DOCUMENTA 18: Université de Barcelona, Institut Català d'Arqueologia Clàssica, Institut National du Patrimoine (Tunisie), Tarragone.

Kassianidou, V. 1992. Monte Romero, a Silver-Producing Workshop of the Seventh Century B.C in SW Spain. Institute for Archaeo-Metallurgical Studies (IAMS) Newsletter 18:37-47.

Kassianidou, V. 2003. Early Extraction of Silver from Complex Polymetallic Ores. In Mining and Metal Production Through the Ages, edited by P. Craddock and J. Lang. London: The British Museum Press.

Katzenstein, Hannah Jacob. 1997. History of Tyre: From the Beginning of the Second Millennium B.C.E. until the Fall of the Neo-Babylonian Empire in 538 B.C.E. Jerusalem: Ben-Gurion University of the Negev Press. 
690

691

692

693

694

695

696

697

698

699

700

701

702

703

Kaufman, Brett. 2013. Copper Alloys from the 'Enot Shuni Cemetery and the Origins of Bronze Metallurgy in the Levant. Archaeometry 55 (4):663-690.

Kaufman, Brett. 2014. Empire Without A Voice: Phoenician Iron Metallurgy and Imperial Strategy at Carthage. Dissertation, University of California, Los Angeles.

Keesmann, I., and B. Hellermann. 1989. Mineralogische und Chemische Untersuchungen an Schlacken von Morro de Mezquitilla. Madrider Mitteilungen 30:92-117.

Keesmann, Ingo. 1994. In Handwerk und Technologie im Alten Orient: ein Beitrag zur Geschichte der Technik im Altertum, edited by R. Wartke: Ph. von Zabern.

Keesmann, Ingo. 2001. Untersuchungen Zur Metallurgie Im Archaischen Und Punischen Karthago. Mediterranean Archaeology 14 (The Origins of Iron Metallurgy):95-108.

Killick, David. 2009. Cairo to Cape: The Spread of Metallurgy Through Eastern and Southern Africa. Journal of World Prehistory 22 (4):399-414.

Killick, David. 2015. Invention and Innovation in African Iron-smelting Technologies. Cambridge Archaeological Journal 25 (01):307-319.

Lancel, Serge. 1981. Fouilles Françaises à Carthage. La Colline de Byrsa et l'Occupation Punique (VIIe siècle - 146 av. J.-C.). Bilan de Sept Années de Fouilles. CRAI Comptes-Rendus des Séances de l'Académie des Inscriptions et Belles-Lettres 125 (2):156-193.

Lancel, Serge. 1985. La Renaissance de la Carthage Punique. Réflexions sur Quelques Enseignements de la Campagne Internationale Patronnée par l'Unesco. CRAI Comptes-Rendus des Séances de l'Académie des Inscriptions et Belles-Lettres 129 (4):727-751.

Lancel, Serge. 1995. Carthage: A History. Translated by A. Nevill. Oxford: Blackwell.

Lancel, Serge, ed. 1979. Byrsa I: Rapports Préliminaires des Fouilles (1974-1976). Rome: École française de Rome.

Lancel, Serge, ed. 1982. Byrsa II: Rapports Préliminaires sur les Fouilles 1977-1978, Niveaux et Vestiges Puniques. Rome: École française de Rome.

Maraoui Telmini, B., F. Chelbi, and R.F. Docter. 2014. Les fouilles Tuniso-Belges du Terrain Bir Massouda (2002-2005): Contribution à la Connaissance de la Topographie de Carthage à l'Époque Archaïque. In Proceedings of the VIth Congress of Phoenician and Punic Studies, Lisbon, (25 septembre - 1 octobre 2005), edited by A. M. Arruda: 906-916.

Maraoui Telmini, B., R.F. Docter, B. Bechtold, F. Chelbi, and W. van de Put. 2014. Defining Punic Carthage. In The Punic Mediterranean: Identities and Identification from Phoenician Settlement to Roman Rule, edited by J. C. Quinn and N. C. Vella. Cambridge: Cambridge University Press.

Margarida Arruda, Ana. 2009. Phoenician Colonization on the Atlantic Coast of the Iberian Peninsula. In Colonial Encounters in Ancient Iberia: Phoenician, Greek, and Indigenous Relations, edited by M. Dietler and C. López-Ruiz. Chicago: University of Chicago Press.

Mazar, Eilat, ed. 2004. The Phoenician Family Tomb N.1 at the Northenr Cemetery of Achziv (10th-6th Centuries BCE), Cuadernos de Arqueología Mediterránea 10. Barcelona.

Morehart, C. T., and K. De Lucia, 2015, Surplus: The Politics of Production and the Strategies of Everyday Life, in Surplus: The Politics of Production and the Strategies of Everday Life, C. T. Morehart, and K. De Lucia, eds., University Press of Colorado, Boulder.

Neville, Ann. 2007. Mountains of Silver and Rivers of Gold: The Phoenicians in Iberia. Edited by R. J. A. Wilson, University of British Columbia Studies in the Ancient World 1: Oxbow.

Niemeyer, H.G., R.F. Docter, K. Schmidt, and B. Bechtold, eds. 2007. Die Ergebnisse Der Hamburger Grabung unter dem Decumanus Maximus. Mainz: Verlag Philipp Von Zabern.

Niemeyer, Hans Georg. 2001. Archaeological Evidence of Early Iron Technology at Carthage and Other Phoenician Settlements. Mediterranean Archaeology 14 (The Origins of Iron Metallurgy):83-93.

Niemeyer, Hans Georg. 2002. The Phoenician Settlement at Toscanos: Urbanization and Function. In The Phoenicians in Spain: An Archaeological Review of the Eighth-Sixth Centuries B.C.E., edited by M. R. Bierling. Winona Lake, Indiana: Eisenbrauns. 
Ortega-Feliu, I., B. Gómez-Tubío, M.Á. Ontalba Salamanca, M.Á. Respaldiza, M.L. de la Bandera, and G. Ovejero Zappino. 2007. Gold and Electrum Jewellry in the Strategic Area of Gadir in Phoenician Period. Nuclear Instruments and Methods in Physics Research 260:329-335.

Phelps, M., 2013, Scientific Examination of Materials Used in the Experiments, in Accidental and Experimental Archaeometallurgy, D. Dungworth, and R. C. P. Doonan, eds., The Historical Metallurgy Society, Occasional Publication No 7.

Radivojević, Miljana, Thilo Rehren, Ernst Pernicka, Dušan Šljivar, Michael Brauns, and Dušan Borić. 2010. On the Origins of Extractive Metallurgy: New Evidence from Europe. Journal of Archaeological Science 37:2775-2787.

Rakob, F. 1989. Karthago. Die fríühe Siedlung. Neue Forschungen. Römische Mitteilungen 96:155-208.

Ramón, Juan. 2002. The Ancient Colonization of Ibiza: Mechanisms and Process. In The Phoenicians in Spain: An Archaeological Review of the Eighth-Sixth Centuries B.C.E., edited by M. R. Bierling. Winona Lake, Indiana: Eisenbrauns.

Renzi, M., and S. Rovira. 2007. Metallurgical Slags from the Phoenician Site of La Fonteta (Alicante), A Preliminary Report. In Avances en Arqueometría 2005. Actas del VI Congreso Ibérico de Arqueometría, Universitat de Girona del 16 al 19 de noviembre de 2005. Girona: Universitat de Girona.

Renzi, Martina, Ignacio Montero-Ruiz, and Michael Bode. 2009. Non-Ferrous Metallurgy from the Phoenician Site of La Fonteta (Alicante, Spain): A Study of Provenance. Journal of Archaeological Science 36:2584-2596.

Ruiz Mata, Diego. 2002. The Ancient Phoenicians of the 8th and 7th Centuries B.C. in the Bay of Cádiz: State of the Research. In The Phoenicians in Spain: An Archaeological Review of the EighthSixth Centuries B.C.E., edited by M. R. Bierling and S. Gitin. Winona Lake, Indiana: Eisenbrauns. Salamanca, M.Á. Ontalba, B. Gómez-Tubío, I. Ortega-Feliu, M.Á. Respaldiza, M. Luisa de la Bandera, G. Ovejero Zappino, A. Bouzas, and A. Gómez Morón. 2006. External-beam PIXE Spectrometry for the Study of Punic Jewellery (SW Spain): The Geopgraphical Provenance of the PalladiumBearing Gold. Nuclear Instruments and Methods in Physics Research B (249):622-627.

Sanmartí, Joan. 2009. Colonial Relations and Social Change in Iberia (Seventh to Third Centuries BC). In Colonial Encounters in Ancient Iberia: Phoenician, Greek, and Indigenous Relations, edited by M. Dietler and C. López-Ruiz. Chicago: University of Chicago Press.

Sanmartí, Joan Grego, Nabil Kallala, M. Carme Belarte, Joan Ramon Torres, Bouthéina Maraoui Telmini, Rafael Jornet, Souad Miniaoui, Thaïs Fadrique, Daniel López Reyes, Núria Morell, Marta Portillo, Sílvia Valenzuela, Jordi Campillo, David Montanero, Francisco Cantero, and Moufida Jenène. 2012. Filling Gaps in the Protohistory of the Eastern Maghreb: The Althiburos Archaeological Project (El Kef, Tunisia). Journal of African Archaeology 10 (1):21-44.

Schmidt, Peter. R. 1997. Iron Technology in East Africa: Symbolism, Science, and Archaeology. Bloomington, Indianapolis, Oxford: Indiana University Press, James Currey.

Shaw, Joseph W. 1989. Phoenicians in Southern Crete. American Journal of Archaeology 93 (2):165-183. Smith, T., 2013, A Report on the Wealden Iron Research Group Smelt, in Accidental and Experimental Archaeometallurgy, D. Dungowrth, and R. C. P. Doonan, eds., The Historical Metallurgy Society, Occasional Publication No 7.Soulignac, R., and V. Serneels, 2013, Forging with Dogon Smiths (Mali), in Accidental and Experimental Archaeometallurgy, D. Dungowrth, and R. C. P. Doonan, eds., The Historical Metallurgy Society, Occasional Publication No 7.

Childs, Terry S., and Eugenia W. Herbert. 2005. Metallurgy and Its Consequences. In African Archaeology: A Critical Introduction, edited by A. B. Stahl: Blackwell Publishing.

Taskinen, Pekka, Markku Kaskiala, Kaisa Miettinen, and Jani Jansson. 2013. Freeze-Lining Formation and Microstructure in a Direct-to-Blister Flash Smelting Slag. Journal for Manufacturing Science and Production 13 (1-2):77-83.

Tylecote, R.F. 1982. Metallurgy in Punic and Roman Carthage. In Mines et Fonderies Antiques de la Gaule. Paris: Centre National de la Recherche Scientifique. 
Valério, Pedro, Rui J.C. Silva, António M. Monge Soares, Maria F. Araújo, Francisco M. Braz Fernandes, António C. Silva, and Luis Berrocal-Rangel. 2010. Technological Continuity in Early Iron Age Bronze Metallurgy at the South-Western Iberian Peninsula - A Sight from Castro dos Ratinhos. Journal of Archaeological Science 37:1811-1819.

Valério, Pedro, António M. Monge Soares, Rui J.C. Silva, Maria Fátima Araújo, Paulo Rebelo, Nuno Neto, Raquel Santos, and Tiago Fontes. 2013. Bronze Production in Southwestern Iberian Peninsula: The Late Bronze Age Metallurgical Workshop from Entre Águas 5 (Portugal). Journal of Archaeological Science 40:439-451.

van Dommelen, Peter. 1998. On Colonial Grounds: A Comparative Study of Colonisalism and Rural Settlement in 1st Milennium BC in West Central Sardinia. Leiden: University of Leiden.

Veldhuijzen, Harald Alexander, and Thilo Rehren. 2007. Slag and the city: early iron production at Tell Hammeh, Jordan, and Tel Beth-Shemesh, Israel. In Metals and Mines: Studies in Archaeometallurgy, edited by S. L. Niece, D. Hook and P. Craddock. London: Archetype/British Museum.

Veldhuijzen, Xander, and Thilo Rehren. 2006. Iron smelting slag formation at Tell Hammeh (Az-Zarqa), Jordan. Paper read at 34th International Syposium on Archaeometry, 3-7 May 2004, at Zaragoza.

Waldbaum, Jane C. 1980. The First Archaeological Appearance of Iron and the Transition to the Iron Age. In The Coming of the Age of Iron, edited by T. A. Wertime and J. D. Muhly. New Haven and London: Yale University Press.

Wolff, Samuel R. 1986. Maritime Trade at Punic Carthage. Ph.D. dissertation, Near Eastern Languages and Civilizations, University of Chicago, Chicago.

\section{Table and Figure Captions}

Table 1. Archaeological strata and historical chronology of Carthage, after Bechtold (2010). (black and white for web and print)

Table 2. PXRF and EDS analytical results of iron ore, iron slag, and Getty bronze standards (wt \%). (color for web and print)

Table 3. Compositional data of slag phases in slagged tuyères (pXRF). (black and white for web and print)

Table 4. Composition of slag in household contexts (under Decumanus Maximus) and Bir Massouda industrial contexts (pXRF). (black and white for web and print)

Table 5. EDS spot compositions of hammerscales and calcium-rich matrix, slag phases, and timber charcoal phases (see Figs. 13 and 14 for images). (black and white for web and print)

Figure 1. Map of Carthage 8th-7th centuries BC with sites and metal workshops mentioned in the text (prepared by Joris Angenon on the basis of Fumadó Ortega 2013, Plano I). (2-column; color for web and print)

Figure 2. Plan of the Bir Massouda site with indication of the individual trenches (AutoCAD version prepared by D. Van Damme, 2005. Plan based on versions of the University of Amsterdam (A. Mezzolani, see fig. 1) and UGent/INP (Société ATHAR, 2003). Reconstruction of the exact position of the house architecture of 'layer IVa' in the excavations of the University of Hamburg is inserted (based on Niemeyer et al. 2007, Beilage 5). (2-column; color for web and print)

Figure 3. Chronological schematic synchronizing major metallurgical, archaeological, and historical periods at Carthage (all dates BC; scale is relative, not temporal)

Figure 4. Ceramic tuyère with attached ferrous slag and hood [8091 17464]. (2-column; color for web and print) 
Figure 5. A selection of tuyères with slag attached from Bir Massouda, with the tuyères in the top left and right corner representative of otherwise poorly preserved specimens but which still display barrels [left to right: top row 8091 18719, 8069 16627, 8091 38018, 8091 17482; middle row 8089 17486, 8091 30191, 8092 17473; bottom row 8091 38027, 8069 16621, 806916622$].$ (2-column; color for web and print)

Figure 6. Slagged tuyères with ferrous and non-ferrous (copper and tin) slag phases excavated at Bir Massouda: (36 tuyères from 800-500 BC; 14 tuyères from 800-400 BC; four tuyères from 200-146 BC). (2-column; black and white for web and print)

Figure 7. Metallographically confirmed slag excavated from the Bir Massouda industrial precinct versus the residential zone under the Decumanus Maximus. (2-column; black and white for web and print)

Figure 8. A selection of slag from Bir Massouda and under the Decumanus Maximus. (i) On the left side slag piece 1249 (525-500 BC), notice the shell encrusted in the slag matrix, on the right side a metallograph showing primary and secondary wüstite phases; (ii) slag piece KA 91/496-17, see also Fig. 12 and Table 4; (iii) slag piece 8339 34910, see Table 4 and Kaufman 2014 Appendix II8; (iv) Early Punic slag piece 7458 40819. (2-column; color for web and print) Figure 9. Mineralized pearlite in iron oxide of corroded object seen at lower (i) and higher (ii) magnifications, VPSEM-EDS GAD [1246]. (2-column; black and white for web and print) Figure 10. Slag phases of the two non-ferrous slagged tuyères. (i) Delafossite laths and spinel microstructure in glassy matrix of non-ferrous slag phase of a slagged tuyère, PLM [1121 17470]; (ii) Leafy microstructure of tin bronze plant-like shoots, delafossite or cassiterite, SEM-EDS GAD [1112 38082]. (2-column; color for web and print)

Figure 11. Typical phases found throughout the corpus of ferrous slag seen in PLM. (i) Slag phase of slagged tuyère with microstructure of secondary wüstite in a glassy matrix [8091 38118]; (ii) Slag with spinels of primary wüstite or magnetite in a glassy matrix with some iron silicates, with a white pure iron prill in the center [8360 34318]; Primary and secondary wüstite in fayalite and glassy matrix of a slag at (iii) further and (iv) closer magnification [8339 34955B] (the entire library of micrographs is available in Kaufman 2014). (2-column; color for web and print)

Figure 12. Fayalite in glassy matrix likely resultant from production of pearlite. (i-iii) The pink circle contains the same area at different magnifications and instruments, respectively PLM, VPSEM-EDS GAD, and dark field; (iv) Fayalite in a crystalline formation [KA91/496-17]. (2column; color for web and print)

Figure 13. Corroded iron metal hammerscale trapped in a non-slag calcium-rich matrix, see Table 5 for spot compositions, VPSEM-EDS GAD [8339 38255A]. (2-column; color for web and print)

Figure 14. Bloomery slag specimens (i) 250445012 and (ii-iv) 1246a. (i) PLM [2504 45012]; (ii) Mineralized ferrite grains PLM [1246a]; (iii) Primary wüstite or magnetite slag phase in glassy matrix can be seen on the upper right of the micrograph, with carburized and iron-mineralized burnt timber fuel cellular structure below, PLM [1246a]; (iv) The black, empty cells rich in carbon whereas the white cells have pseudomorphed into a warped metalliferous tree anatomy, see Table 5 for spot compositions, VPSEM-EDS GAD [1246a]. (2-column; color for web and print) 


\section{Table 1}

\begin{tabular}{lcc}
\hline \hline Period & Dates BC & Description \\
Early Punic (EP) & & \\
Early Punic I & $760-675$ & colonial \\
Early Punic II & $675-530$ & imperial formative \\
Middle Punic (MP) & & \\
Early/Middle Punic & $530-480$ & imperial formative \\
Middle Punic I & $480-430$ & imperial \\
Middle Punic II.1 & $430-400$ & imperial \\
Middle Punic II.2 & $400-300$ & imperial \\
Late Punic (LP) & & \\
Late Punic I & $300-200$ & decline \\
Late Punic II & $200-146$ & collapse \\
\hline \hline
\end{tabular}


Table 2

\begin{tabular}{lcccccccccccc}
\hline \hline Slag BCS 382/1* & $\mathbf{F e O}$ & $\mathbf{C a O}$ & $\mathbf{S i O}_{\mathbf{2}}$ & $\mathbf{P}_{\mathbf{2}} \mathbf{O}_{\mathbf{5}}$ & $\mathbf{S O}_{\mathbf{3}}$ & $\mathbf{A l}_{\mathbf{2}} \mathbf{O}_{\mathbf{3}}$ & $\mathbf{M n O}$ & $\mathbf{T i O}_{2}$ & $\mathbf{M g O}$ & $\mathbf{V}_{\mathbf{2}} \mathbf{O}_{\mathbf{5}}$ & $\mathbf{C r}_{\mathbf{2}} \mathbf{O}_{\mathbf{3}} \mathbf{T o t a l}$ \\
\hline Standard & 25.60 & 40.10 & 13.03 & 3.06 & 0.92 & 3.79 & 7.96 & 0.42 & 3.73 & 0.24 & 0.80 & 99.65 \\
pXRF & 24.84 & 36.34 & 12.39 & 2.64 & 2.01 & 4.58 & 8.22 & nd & nd & nd & 0.72 & 91.74 \\
EDS & 26.78 & 43.79 & 11.66 & 2.69 & 0.65 & 5.43 & 6.69 & 0.88 & 1.90 & 0.34 & 0.90 & 101.71 \\
EDS $\sigma$ & 4.41 & 2.63 & 1.03 & 0.28 & 0.18 & 0.3 & 1.44 & 0.09 & 0.32 & 0.03 & 0.11 & \\
\hline
\end{tabular}

\begin{tabular}{lccccccccccl}
\hline Ore NIST 692 & $\mathbf{F e O}$ & $\mathbf{C a O}$ & $\mathbf{S i O}_{\mathbf{2}}$ & $\mathbf{K}_{\mathbf{2}} \mathbf{O}$ & $\mathbf{P}_{\mathbf{2}} \mathbf{O}_{\mathbf{5}}$ & $\mathbf{S O}_{\mathbf{3}}$ & $\mathbf{A l}_{\mathbf{2}} \mathbf{O}_{\mathbf{3}}$ & $\mathbf{M n O}$ & $\mathbf{T i O}_{2}$ & $\mathbf{M g O}$ & Total \\
Standard & 76.65 & 0.023 & 10.14 & 0.039 & 0.09 & 0.012 & 1.41 & 0.46 & 0.045 & 0.035 & 88.9 \\
pXRF & 80.17 & nd & 11.79 & nd & nd & nd & 2.78 & 0.52 & nd & nd & 95.26 \\
EDS & 80.2 & 0.05 & 11.61 & 0.04 & 0.14 & 0.01 & 3.23 & 0.55 & 0.11 & 0.06 & 96 \\
EDS $\sigma$ & 2.18 & 0.03 & 1.53 & 0.02 & 0.02 & 0.01 & 0.36 & 0.04 & 0.02 & 0.03 & \\
\hline
\end{tabular}

E - British auger cover plate (19th century)

\begin{tabular}{lcccccccccc}
\hline Elements & Fe & $\mathbf{C u}$ & Sn & Pb & As & Zn & Ni & Sb & Bi & Total \\
\hline Getty standard & 0.41 & 70.0 & 0.53 & $<1.22$ & 0.29 & 28.0 & $<0.35$ & $<0.12$ & $<0.12$ & 101.04 \\
pXRF & 0.41 & 70.0 & 0.549 & 0.97 & nd & 28.0 & 0.06 & 0.03 & 0.12 & 100.14 \\
pXRF (3 mm spot) & 0.40 & 70.0 & 0.55 & 0.97 & nd & 28.0 & 0.06 & 0.03 & 0.13 & 100.14 \\
\hline
\end{tabular}

\section{K - MBH 31X B27 A (CRM)}

\begin{tabular}{lcccccccccc}
\hline Elements & Fe & Cu & Sn & Pb & As & Zn & Ni & Sb & Bi & Total \\
\hline Getty standard & 0.31 & 78.2 & 0.92 & 0.24 & 0.03 & 19.9 & 0.04 & 0.04 & 0.06 & 99.74 \\
pXRF & 0.32 & 78.1 & 0.905 & 0.24 & nd & 19.8 & 0.04 & 0.03 & 0.06 & 99.50 \\
pXRF (3 mm spot) & 0.33 & 78.0 & 0.95 & 0.27 & nd & 19.7 & 0.04 & 0.04 & 0.07 & 99.4 \\
\hline \hline
\end{tabular}

*F of $0.1 \mathrm{wt} \%$ excluded from standard composition and measurements 
Table 3

\begin{tabular}{|c|c|c|c|c|c|c|c|c|c|c|c|c|c|c|}
\hline \multicolumn{15}{|l|}{$\overline{800-500 B C}$} \\
\hline Artifact & Dates BC & Spots & $\mathrm{FeO}$ & $\mathrm{CaO}$ & $\mathrm{SiO}_{2}$ & $\mathrm{~K}_{2} \mathrm{O}$ & $\mathbf{P}_{2} \mathbf{O}_{5}$ & $\mathrm{SO}_{3}$ & $\mathrm{Al}_{2} \mathrm{O}_{3}$ & MnO & $\mathrm{CuO}$ & $\mathrm{SnO}_{2}$ & $\mathrm{PbO}$ & Total \\
\hline 111238082 & $650-580$ & 2 & 5.8 & 2.1 & 35.4 & 1.1 & 0.3 & 0.3 & 2.5 & 0.2 & 7.3 & 0.3 & 0.037 & 55.3 \\
\hline 112117470 & $760-600$ & 1 & 12.7 & 7.1 & 55.6 & 3.0 & 1.6 & 0.6 & 7.7 & 1.3 & 3.0 & 0.2 & 0.022 & 92.9 \\
\hline 806617267 & $700-500$ & 1 & 10.7 & 6.6 & 50.4 & 2.5 & 2.0 & 0.2 & 7.5 & - & - & - & - & 79.9 \\
\hline 806916621 & $700-500$ & 1 & 14.1 & 4.9 & 30.1 & 1.7 & 1.1 & 0.1 & 3.5 & 1.0 & - & - & - & 56.5 \\
\hline 806916622 & $700-500$ & 2 & 7.2 & 5.4 & 40.4 & 2.4 & 2.0 & 0.8 & 5.6 & 0.4 & - & - & - & 64.1 \\
\hline 806916624 & $700-500$ & 1 & 14.9 & 9.6 & 38.8 & 1.5 & 2.5 & 0.2 & 4.9 & 1.0 & - & - & - & 73.5 \\
\hline 806916627 & $700-500$ & 3 & 14.9 & 6.1 & 36.0 & 2.3 & 1.4 & 0.5 & 6.2 & 0.4 & - & - & - & 68.0 \\
\hline 806916628 & $700-500$ & 1 & 11.8 & 7.6 & 38.6 & 1.9 & 2.6 & 0.5 & 6.7 & 1.0 & - & - & - & 70.6 \\
\hline 808517471 & $750-650$ & 3 & 9.3 & 7.9 & 46.3 & 1.7 & 2.6 & 0.2 & 6.2 & 0.5 & - & - & - & 74.7 \\
\hline 809112679 & $700-500$ & 1 & 11.7 & 11.0 & 23.2 & 1.3 & 2.5 & 0.2 & 2.1 & 0.9 & - & - & - & 52.8 \\
\hline 809117464 & $700-500$ & 3 & 18.5 & 8.7 & 34.2 & 1.9 & 2.5 & - & 6.3 & 0.5 & - & - & - & 72.5 \\
\hline 809117468 & $700-500$ & 2 & 18.0 & 7.4 & 39.6 & 1.7 & 2.4 & 0.1 & 7.8 & 0.8 & - & - & - & 77.9 \\
\hline 809117469 & $700-500$ & 1 & 6.8 & 4.4 & 27.3 & 1.5 & 1.0 & - & 2.2 & 0.5 & - & - & - & 43.7 \\
\hline 809117481 & $700-500$ & 3 & 19.0 & 8.3 & 35.8 & 1.5 & 3.0 & 0.2 & 5.7 & 0.8 & - & - & - & 74.1 \\
\hline 809117482 & $700-500$ & 2 & 9.7 & 10.1 & 46.1 & 2.4 & 1.4 & 0.2 & 8.3 & 0.7 & - & - & - & 78.8 \\
\hline 809118719 & $700-500$ & 3 & 15.7 & 9.1 & 38.7 & 1.5 & 2.0 & 0.2 & 6.2 & 1.1 & - & - & - & 74.6 \\
\hline 809130191 & $700-500$ & 2 & 15.8 & 6.5 & 44.1 & 2.3 & 3.1 & - & 7.7 & 1.0 & - & - & - & 80.4 \\
\hline 809137992 & $700-500$ & 1 & 18.8 & 10.6 & 34.7 & 1.3 & 2.4 & 0.2 & 1.0 & 2.1 & - & - & 0.005 & 77.1 \\
\hline 809138018 & $700-500$ & 3 & 25.7 & 6.9 & 24.5 & 1.5 & 0.7 & - & .9 & 0.8 & - & - & - & 65.1 \\
\hline 8091 & 700 & 2 & 9.3 & 11.8 & 39.2 & 1.5 & 3.3 & 0. & 1.0 & 0.5 & - & - & 0.028 & 72.9 \\
\hline 809138034 & $700-500$ & 1 & 6.1 & 2.2 & 37.1 & 1.5 & 0.9 & 0.4 & 1.0 & - & - & - & - & 49.1 \\
\hline 809138038 & $700-500$ & 1 & 6.7 & 1.5 & 39.9 & 1.5 & 0.3 & 0.3 & - & - & - & - & - & 50.1 \\
\hline 809138039 & $700-500$ & 3 & 8.3 & 9.2 & 48.8 & 3.1 & 2.6 & - & 7.6 & 0.3 & - & - & - & 80.0 \\
\hline 809138042 & $700-500$ & 3 & 6.8 & 6.9 & 50.2 & 1.8 & 2.1 & - & 7.5 & 0.3 & - & - & - & 75.6 \\
\hline 809138096 & $700-500$ & 1 & 6.4 & 3.3 & 24.5 & 0.9 & 0.7 & - & 1.8 & - & - & - & - & 37.6 \\
\hline 809138111 & $700-500$ & 2 & 9.1 & 6.7 & 46.6 & 2.0 & 1.2 & - & 7.9 & 0.5 & - & - & 0.005 & 73.9 \\
\hline 809138118 & $700-500$ & 3 & 16.4 & 8.9 & 41.2 & 1.7 & 0.8 & - & 8.7 & 0.3 & - & - & - & 78.1 \\
\hline 809138212 & $700-500$ & 1 & 27.7 & 7.0 & 17.5 & 0.9 & 0.7 & - & 2.6 & 0.5 & - & - & - & 57.0 \\
\hline 809138214 & $700-500$ & 2 & 8.4 & 7.3 & 50.7 & 1.8 & 0.6 & 0.2 & 8.4 & - & - & - & - & 77.4 \\
\hline 809138215 & $700-500$ & 1 & 26.4 & 4.5 & 46.5 & 3.1 & 1.2 & 0.8 & 10.3 & 0.7 & - & - & - & 93.4 \\
\hline 821049138 & $750-600$ & 3 & 11.1 & 12.8 & 37.2 & 1.4 & 2.9 & 0.1 & 5.8 & 0.7 & - & - & - & 72.1 \\
\hline 821049141 & $750-600$ & 2 & 14.0 & 15.5 & 35.1 & 1.7 & 3.1 & 0.2 & 6.4 & 0.5 & - & - & 0.013 & 76.5 \\
\hline 821732232 & $800-530$ & 1 & 12.0 & 7.8 & 41.4 & 1.8 & 2.2 & - & 7.4 & - & - & - & - & 72.7 \\
\hline 821732233 & $800-5$ & 3 & 12.9 & 7.2 & 46.3 & 2.3 & 3.1 & 0.4 & 5.0 & 0.9 & - & - & - & 78.0 \\
\hline 821749145 & 800 & 1 & 10.3 & 8.6 & 50.1 & 2.5 & 4.2 & - & 7.1 & 0.9 & - & - & 0.006 & 83.7 \\
\hline 821749154 & $800-530$ & 1 & 6.5 & 6.5 & 48.8 & 1.6 & 0.6 & - & 10.4 & - & - & - & - & 74.4 \\
\hline
\end{tabular}

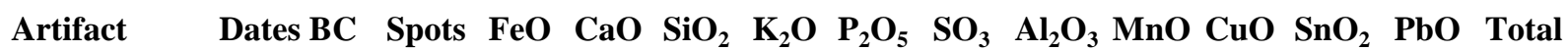
$\begin{array}{lllllllllllllll}109338011 & 450-425 & 2 & 5.2 & 8.0 & 57.5 & 2.1 & 1.5 & 0.3 & 5.3 & 1.2 & - & - & 004 & 81.1\end{array}$

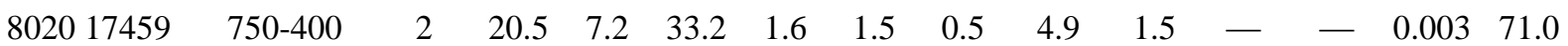

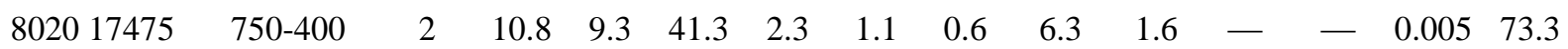
$\begin{array}{lllllllllllllll}806837993 & 800-450 & 1 & 5.7 & 4.4 & 54.7 & 1.7 & 0.3 & - & 13.2 & - & - & - & - & 80.1\end{array}$

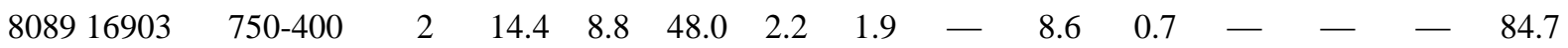
$\begin{array}{llllllllllllllll}8089 & 17486 & 750-400 & 2 & 20.1 & 7.4 & 46.0 & 2.6 & 3.7 & - & 6.7 & 0.8 & - & - & 0.004 & 87.3\end{array}$

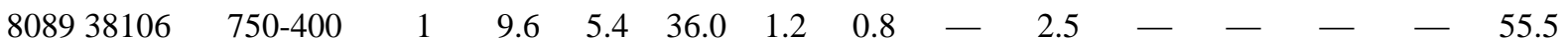
$\begin{array}{lllllllllllllll}8092 & 750-400 & 1 & 13.5 & 8.1 & 35.9 & 1.5 & 1.0 & - & 3.6 & 1.3 & - & - & - & 64.9\end{array}$ $\begin{array}{lllllllllllllll}8092 & 17472 & 750-400 & 2 & 18.3 & 7.0 & 44.9 & 2.5 & 0.8 & 0.3 & 8.0 & 0.6 & - & - & -\end{array} 82.4$ $\begin{array}{lllllllllllllll}8092 & 17473 & 750-400 & 2 & 15.5 & 8.3 & 33.6 & 1.6 & 1.0 & 0.2 & 5.9 & 0.9 & - & - & -\end{array} 66.9$ $\begin{array}{lllllllllllllll}8092 & 17479 & 750-400 & 1 & 6.4 & 4.0 & 49.3 & 2.7 & 1.4 & - & 10.9 & 0.5 & - & - & -\end{array}$

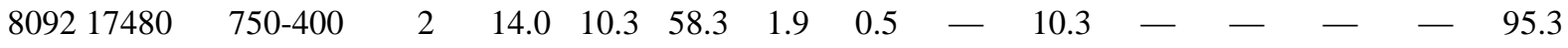
$\begin{array}{lllllllllllllll}809238015 & 750-400 & 2 & 31.7 & 10.2 & 31.3 & 1.3 & 0.9 & 0.2 & 7.5 & 0.5 & - & - & 0.024 & 83.7\end{array}$ 


\begin{tabular}{|c|c|c|c|c|c|c|c|c|c|c|c|c|c|c|}
\hline 0993 & 0 & 1 & 5.8 & 4.5 & 42.2 & 1.1 & .8 & - & 2.9 & - & - & - & - & 57.3 \\
\hline \multicolumn{15}{|l|}{$200-146 B C$} \\
\hline Arti & D & pots & Fe & $\mathrm{CaO}$ & & $\mathrm{K}_{2} \mathrm{O}$ & $\mathrm{O}_{5}$ & $\mathrm{SO}_{3}$ & 3 & InO & 10 & $\mathrm{SnO}_{2}$ & b0 & Total \\
\hline & & 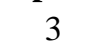 & & 88 & & 10 & 25 & 01 & & 0.4 & - & - & 0.003 & 71.7 \\
\hline & & 1 & & 9.9 & & & & & & & 0.1 & - & - & \\
\hline & & & & 9. & 50 & & & 0. & & & - & - & 0.050 & 79.3 \\
\hline 09638001 & $200-146$ & 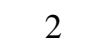 & 12.8 & 9.8 & 31.1 & 1.6 & 1.4 & 0.3 & 6.0 & 1.2 & - & - & 0.010 & 64.3 \\
\hline
\end{tabular}


Table 4

\begin{tabular}{|c|c|c|c|c|c|c|c|c|c|c|c|c|c|}
\hline \multicolumn{14}{|c|}{$\begin{array}{l}\text { Under Decumanus Maximus } \\
700-550 B C\end{array}$} \\
\hline Artifact & Dates BC & Spots & $\mathrm{FeO}$ & $\mathrm{CaO}$ & $\mathrm{SiO}_{2}$ & $\mathbf{K}_{2} \mathbf{O}$ & $\mathbf{P}_{2} \mathbf{O}_{5}$ & $\mathrm{SO}_{3}$ & $\mathbf{A l}_{2} \mathbf{O}_{3}$ & MnO & $\mathrm{CuO}$ & PbO & Total \\
\hline KA86/113-61 & $700-675$ & 2 & 11.0 & 6.0 & 53.2 & 2.4 & 5.6 & - & 6.0 & - & - & - & 84.2 \\
\hline KA88/41-1 & $600-550$ & 2 & 43.5 & 10.5 & 15.3 & 1.0 & 6.1 & 0.4 & 2.4 & - & 0.1 & - & 79.2 \\
\hline KA91/496-17 & $\sim 675$ & 1 & 29.6 & 9.5 & 17.2 & 1.3 & 4.3 & 0.1 & 0.7 & - & - & - & 62.6 \\
\hline \multicolumn{14}{|l|}{$\begin{array}{l}\text { Bir Massouda } \\
800-600 \text { BC }\end{array}$} \\
\hline Artifact & Dates BC & Spots & $\mathrm{FeO}$ & $\mathrm{CaO}$ & $\mathrm{SiO}_{2}$ & $\mathbf{K}_{2} \mathbf{O}$ & $\mathbf{P}_{2} \mathbf{O}_{5}$ & $\mathrm{SO}_{3}$ & $\mathrm{Al}_{2} \mathrm{O}_{3}$ & MnO & $\mathrm{CuO}$ & PbO & Total \\
\hline 334834318 & $800-700$ & 1 & 9.2 & 3.2 & 25.5 & 2.3 & 1.4 & 0.5 & - & 0.9 & - & - & 42.9 \\
\hline $8210 \mathrm{~A}$ & $750-600$ & 1 & 14.0 & 15.4 & 32.9 & 1.7 & 5.0 & 0.2 & 5.7 & 1.0 & - & 0.009 & 75.8 \\
\hline $8210 \mathrm{C}$ & $750-600$ & 2 & 57.6 & 6.8 & 22.7 & 1.0 & 1.2 & 1.8 & 7.4 & - & - & 0.008 & 98.5 \\
\hline $8210 \mathrm{D}$ & $750-600$ & 2 & 31.6 & 14.0 & 29.1 & 1.2 & 4.2 & 0.2 & 6.7 & - & - & 0.003 & 87.1 \\
\hline 833934910 & $800-600$ & 2 & 5.4 & 9.9 & 59.7 & 1.5 & 0.8 & 0.2 & 4.5 & - & - & - & 82 \\
\hline 833934919 & $800-600$ & 2 & 25.1 & 8.4 & 23.7 & 1.2 & 1.7 & 0.5 & - & 1.7 & - & - & 62.3 \\
\hline $833934955 \mathrm{~A}$ & $800-600$ & 1 & 62.6 & 1.4 & 12.2 & 0.6 & 0.5 & 0.8 & - & - & - & - & 78.1 \\
\hline $833934955 \mathrm{~B}$ & $800-600$ & 1 & 78.8 & 2.0 & 8.4 & 0.2 & 0.5 & 0.6 & - & - & - & - & 90.6 \\
\hline $833938255 \mathrm{~A}$ & $800-600$ & 1 & 61.5 & 6.6 & 13.8 & 0.5 & - & 0.6 & - & - & - & - & 83 \\
\hline $833938255 \mathrm{~B}$ & $800-600$ & 1 & 18.0 & 3.9 & 17.9 & 0.7 & 0.5 & 0.5 & - & - & - & - & 41.4 \\
\hline 836034930 & $700-600$ & 1 & 51.6 & 5.8 & 13.3 & 0.3 & - & 0.3 & - & - & - & - & 71.3 \\
\hline \multicolumn{14}{|l|}{$\begin{array}{l}\text { Bir Massouda } \\
550-475 \text { BC }\end{array}$} \\
\hline Artifact & Dates BC & Spots & $\mathrm{FeO}$ & $\mathrm{CaO}$ & $\mathrm{SiO}_{2}$ & $\mathbf{K}_{2} \mathbf{O}$ & $\mathbf{P}_{2} \mathbf{O}_{5}$ & $\mathrm{SO}_{3}$ & $\mathrm{Al}_{2} \mathrm{O}_{3}$ & MnO & $\mathrm{CuO}$ & PbO & Total \\
\hline 111338057 & $525-475$ & 2 & 51.1 & 5.5 & 8.2 & 0.4 & 2.1 & 0.7 & 0.9 & - & - & 0.013 & 68.8 \\
\hline 1249 & $525-500$ & 1 & 61.1 & 15.4 & 3.5 & 0.1 & 0.9 & 0.2 & - & - & - & 0.010 & 81.2 \\
\hline \multicolumn{14}{|l|}{$\begin{array}{l}\text { Bir Massouda } \\
330-300 \text { BC }\end{array}$} \\
\hline Artifact & Dates BC & Spots & $\mathrm{FeO}$ & $\mathrm{CaO}$ & $\mathrm{SiO}_{2}$ & $\mathbf{K}_{2} \mathbf{O}$ & $\mathbf{P}_{2} \mathbf{O}_{5}$ & $\mathrm{SO}_{3}$ & $\mathrm{Al}_{2} \mathrm{O}_{3}$ & MnO & $\mathrm{CuO}$ & PbO & Total \\
\hline 250445012 & $330-300$ & 1 & 62.8 & 3.1 & 10.8 & 0.3 & 1.1 & 0.7 & - & - & - & - & 78.8 \\
\hline
\end{tabular}


Table 5

\begin{tabular}{lccccccccccc}
\hline \hline Figure 13 & & & & & & & & & & & \\
Artifact 8339 38255A & $\mathbf{F e}$ & $\mathbf{O}$ & $\mathbf{C}$ & $\mathbf{C a}$ & $\mathbf{S i}$ & $\mathbf{S}$ & $\mathbf{A l}$ & $\mathbf{N a}$ & $\mathbf{M g}$ & Total \\
yellow dot & 3.0 & 50.2 & 7.0 & 34.0 & 0.8 & 0.1 & 0.2 & 0.2 & 4.6 & 100.0 & \\
pink dot & 71.0 & 24.9 & 3.1 & 0.4 & 0.6 & - & 0.1 & - & - & 100.0 & \\
blue dot & 72.2 & 24.2 & 2.1 & 0.8 & 0.6 & - & 0.1 & - & - & 100.0 \\
\hline Figure 14ii & & & & & & & & & & & \\
Artifact 1246a (slag) & $\mathbf{F e}$ & $\mathbf{O}$ & $\mathbf{C}$ & $\mathbf{S i}$ & $\mathbf{A l}$ & Total & & & & & \\
pink dot & 77.3 & 21.2 & 1.1 & 0.2 & 0.1 & 100.0 & & & & & \\
\hline Figure 14iv & & & & & & & & & & & \\
Artifact 1246a (timber) & $\mathbf{F e}$ & $\mathbf{O}$ & $\mathbf{C}$ & $\mathbf{C a}$ & $\mathbf{S i}$ & $\mathbf{K}$ & $\mathbf{S}$ & $\mathbf{C u}$ & $\mathbf{N a}$ & $\mathbf{M g}$ & Total \\
yellow dot & 4.3 & 8.3 & 71.8 & 1.5 & 13.1 & 0.3 & - & 0.4 & 0.3 & 0.1 & 100.01 \\
pink dot & 7.7 & 13.0 & 73.3 & 1.9 & 2.5 & 0.3 & 0.1 & 0.7 & 0.4 & 0.1 & 99.98 \\
blue dot & 57.9 & 5.2 & 30.0 & 1.5 & 4.6 & 0.2 & - & 0.3 & 0.2 & 0.1 & 100.00 \\
green dot & 42.7 & 10.7 & 28.5 & 0.4 & 17.4 & 0.1 & - & - & 0.1 & 0.1 & 100.00 \\
\hline \hline
\end{tabular}




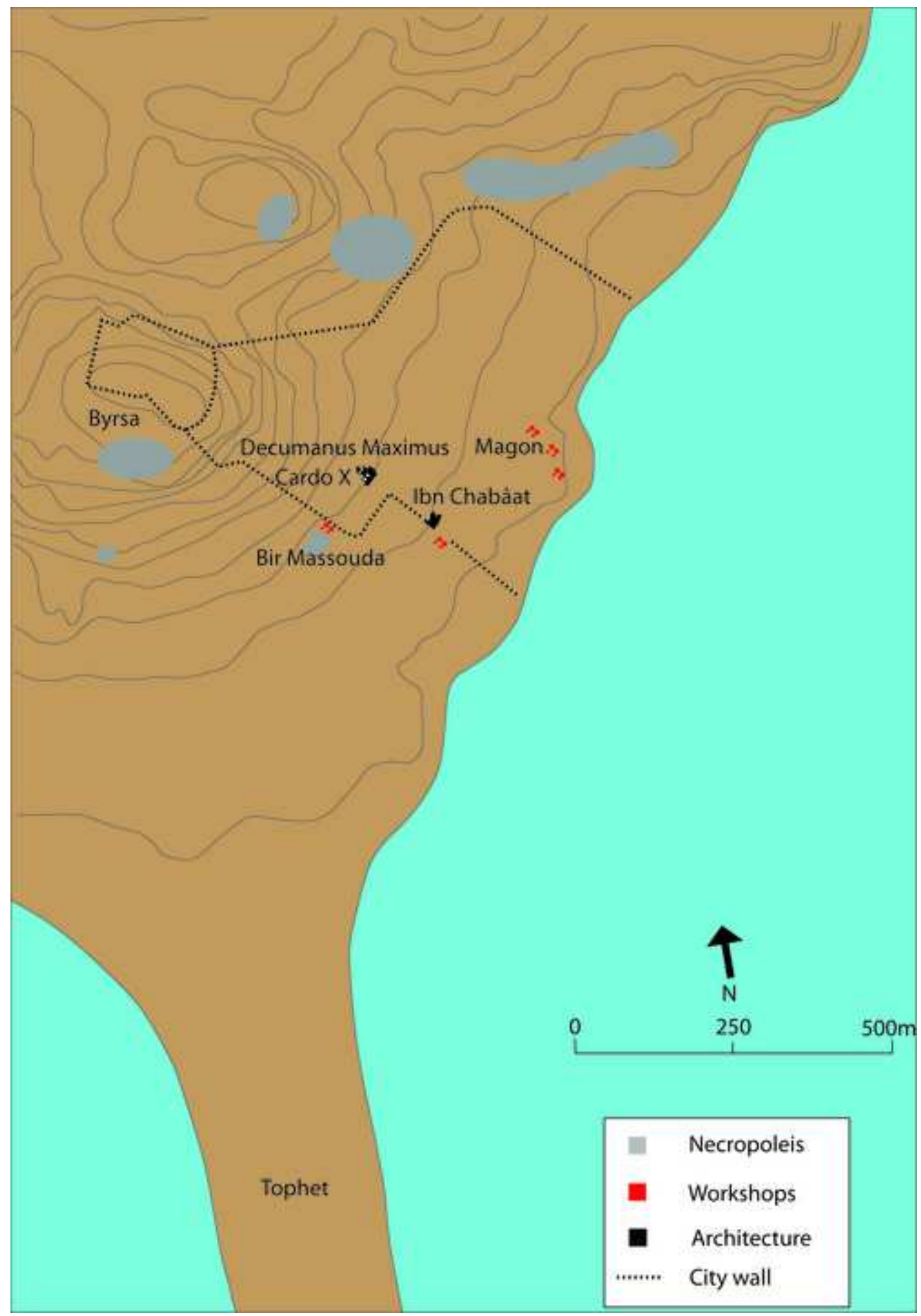




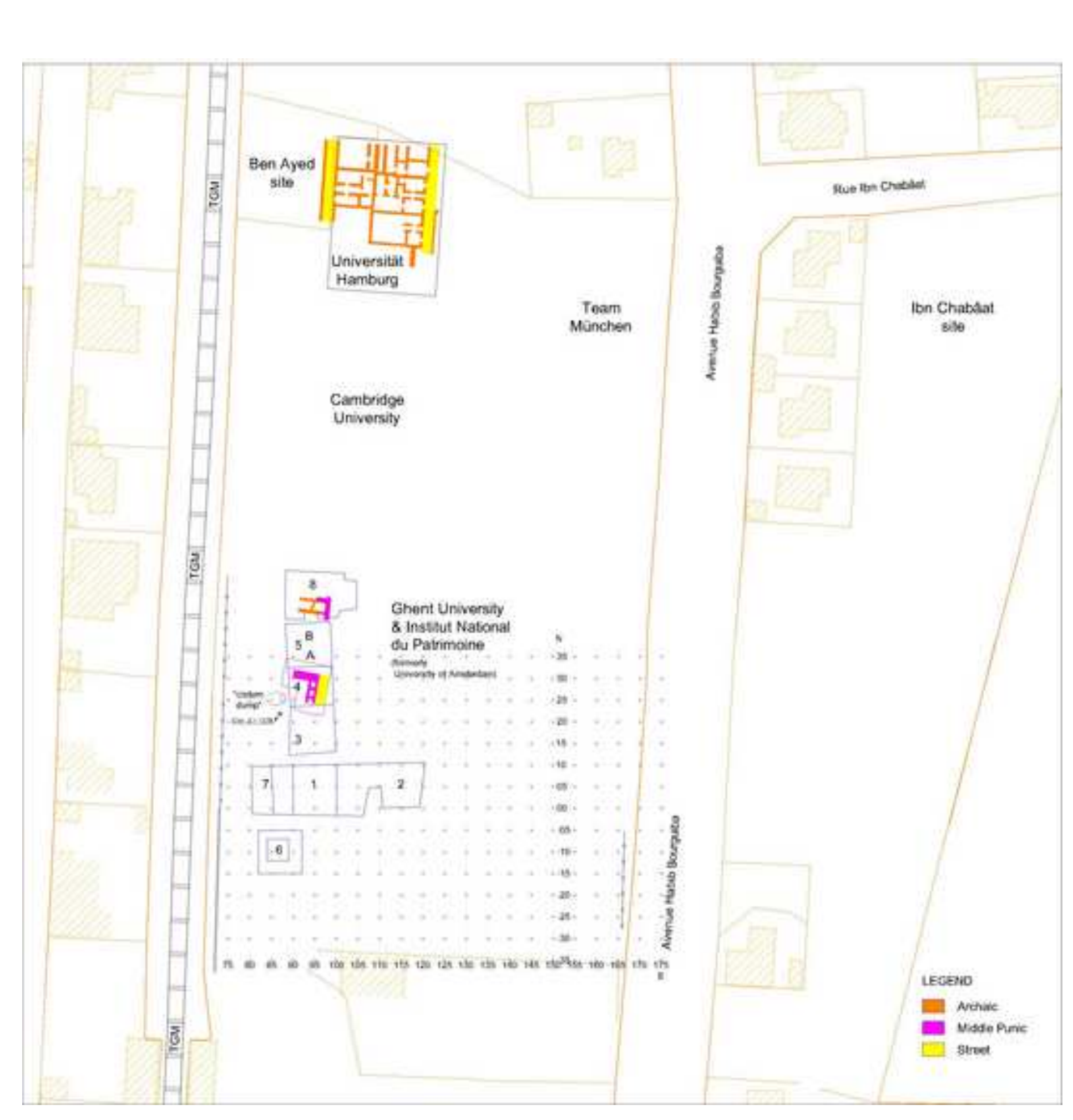

Figure 2

\section{Figure 2}

.

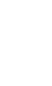

-




\section{Metallurgical periods}

Bar Massouda $(760-400)$

Under Dectonanus Maximus (700-550)

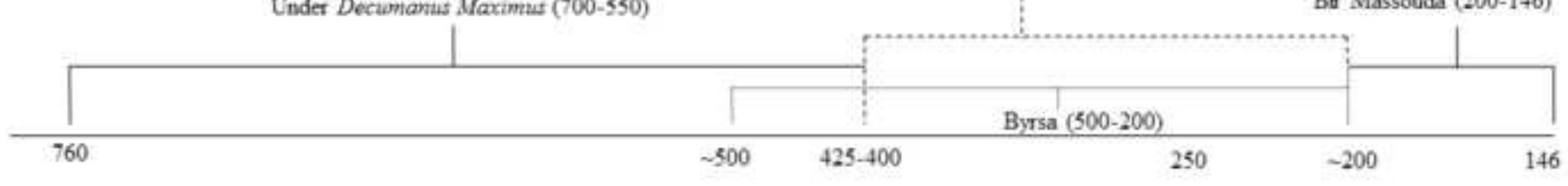

\section{Archaeological periods}

Middle Punic 1

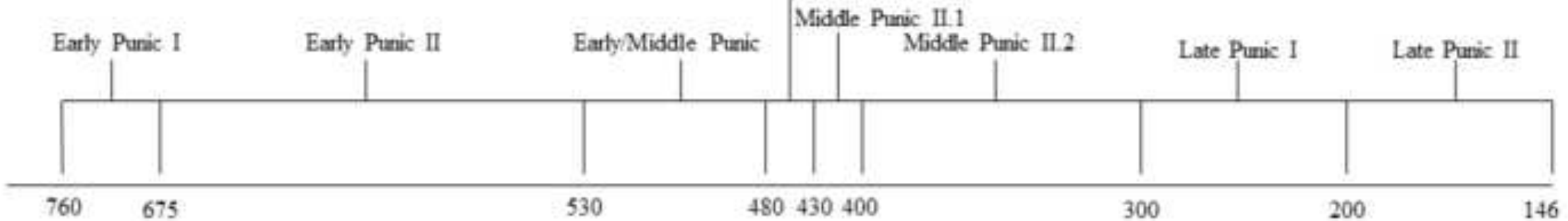

\section{Historical events}

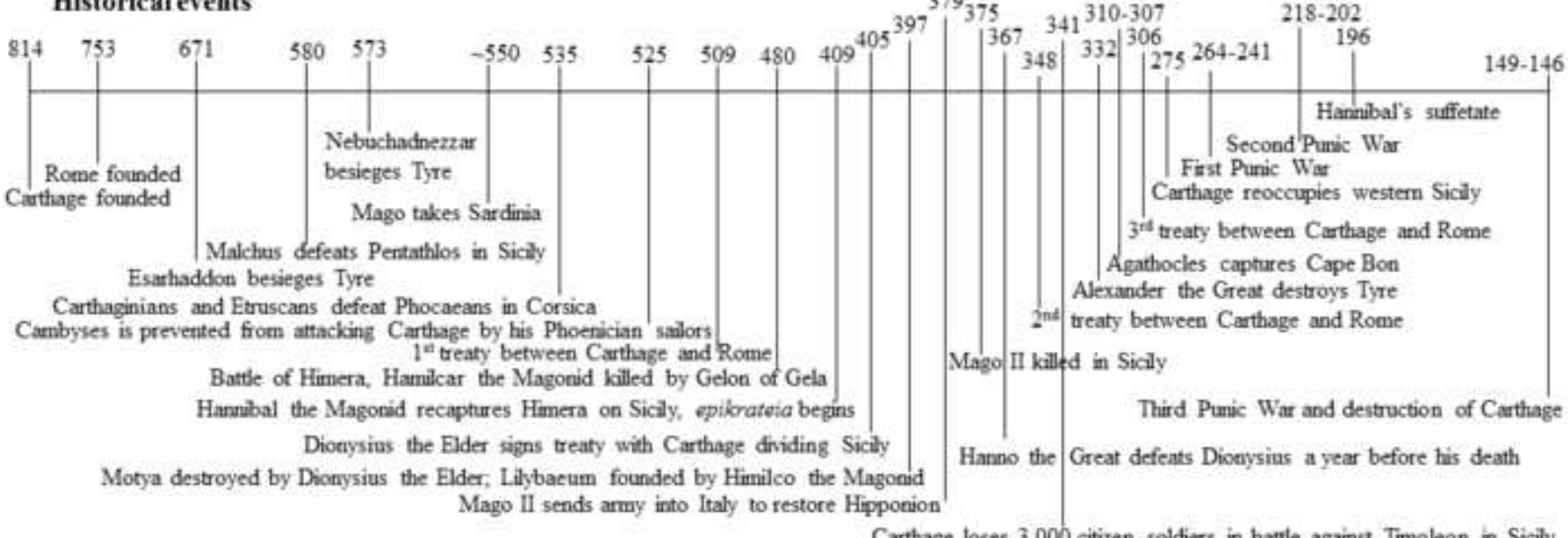

Carthage loses 3,000 citizen soldiers in battle against Timoleon in Sicily 


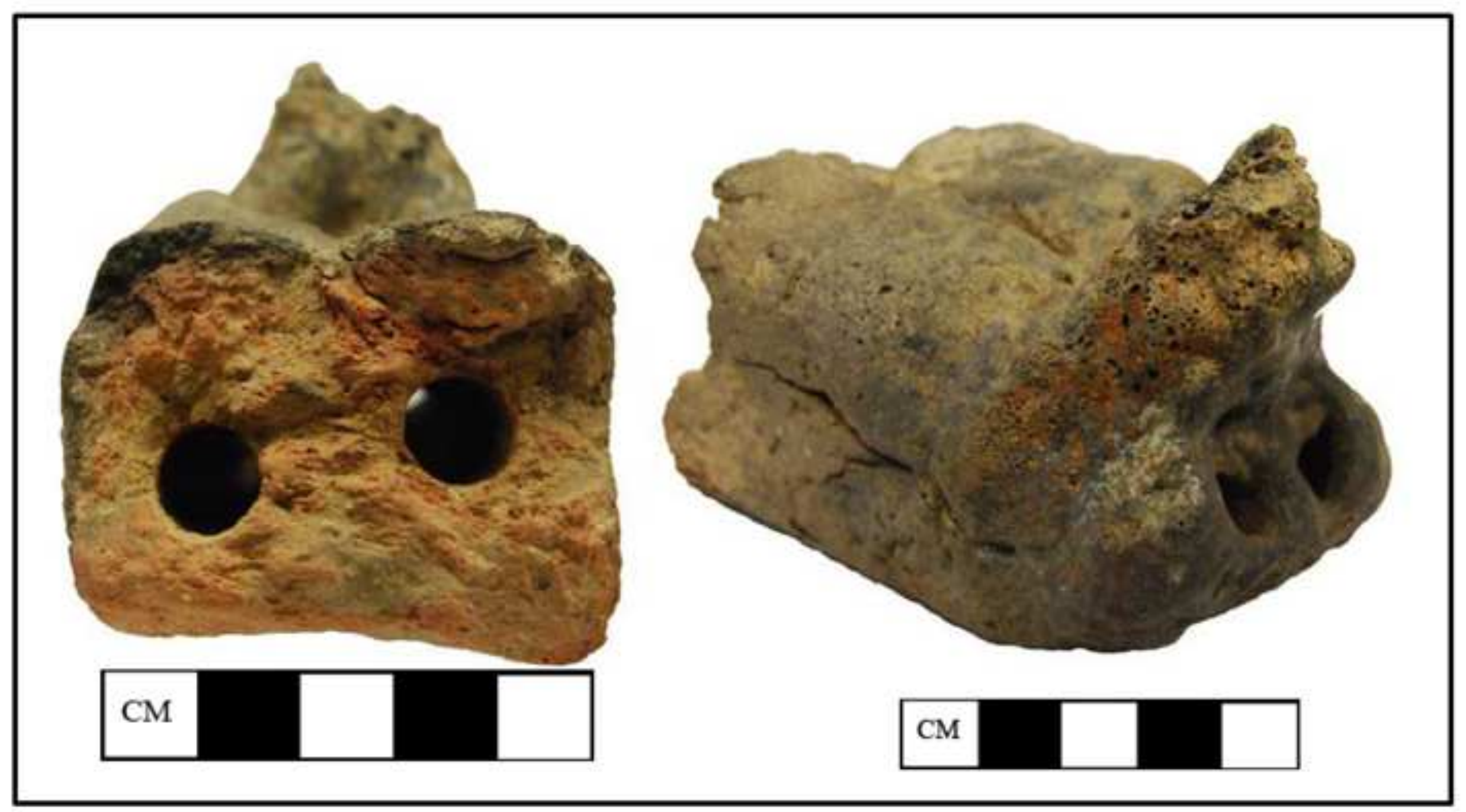




\section{Figure 7

.

(2)

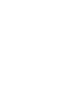

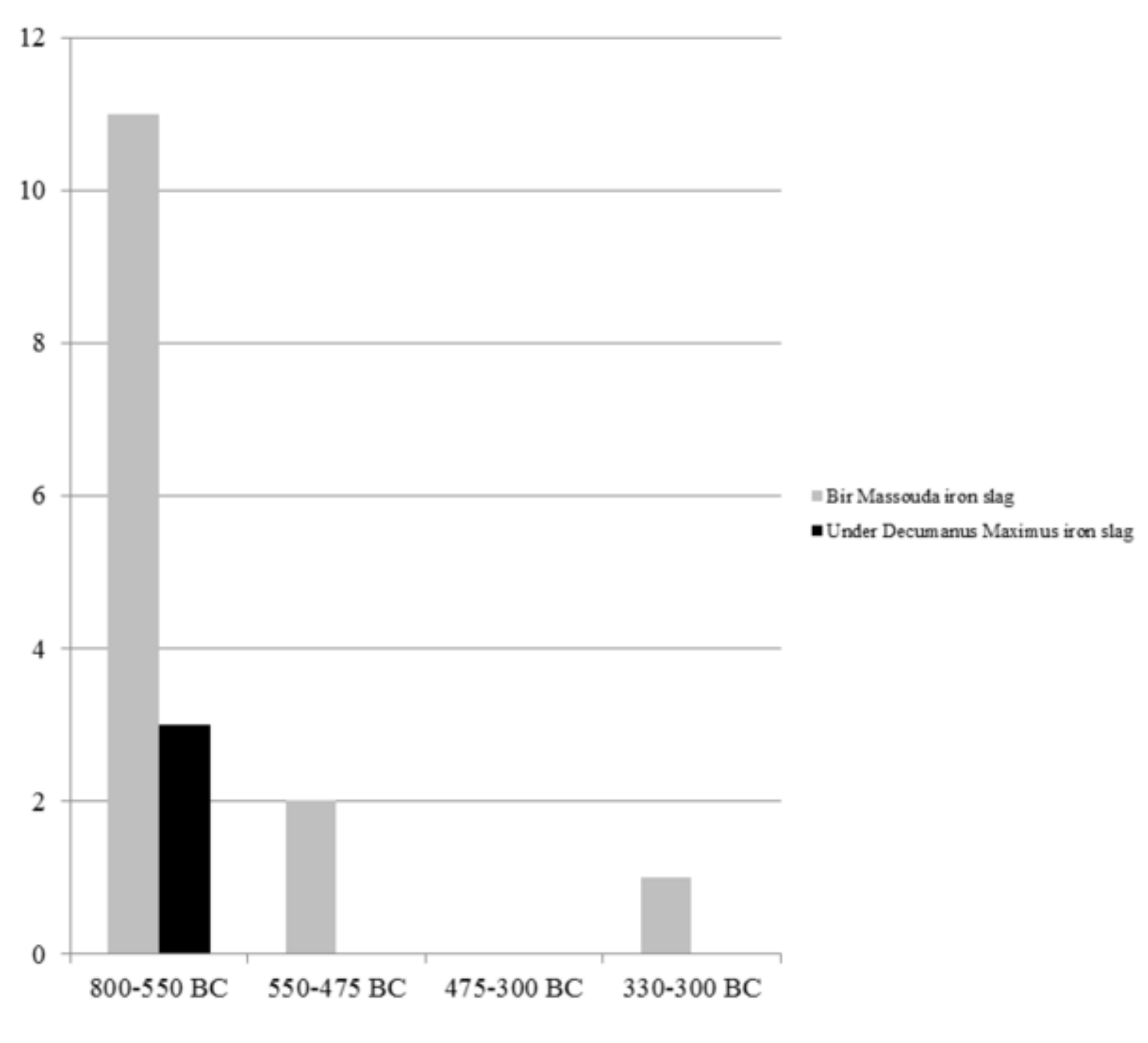

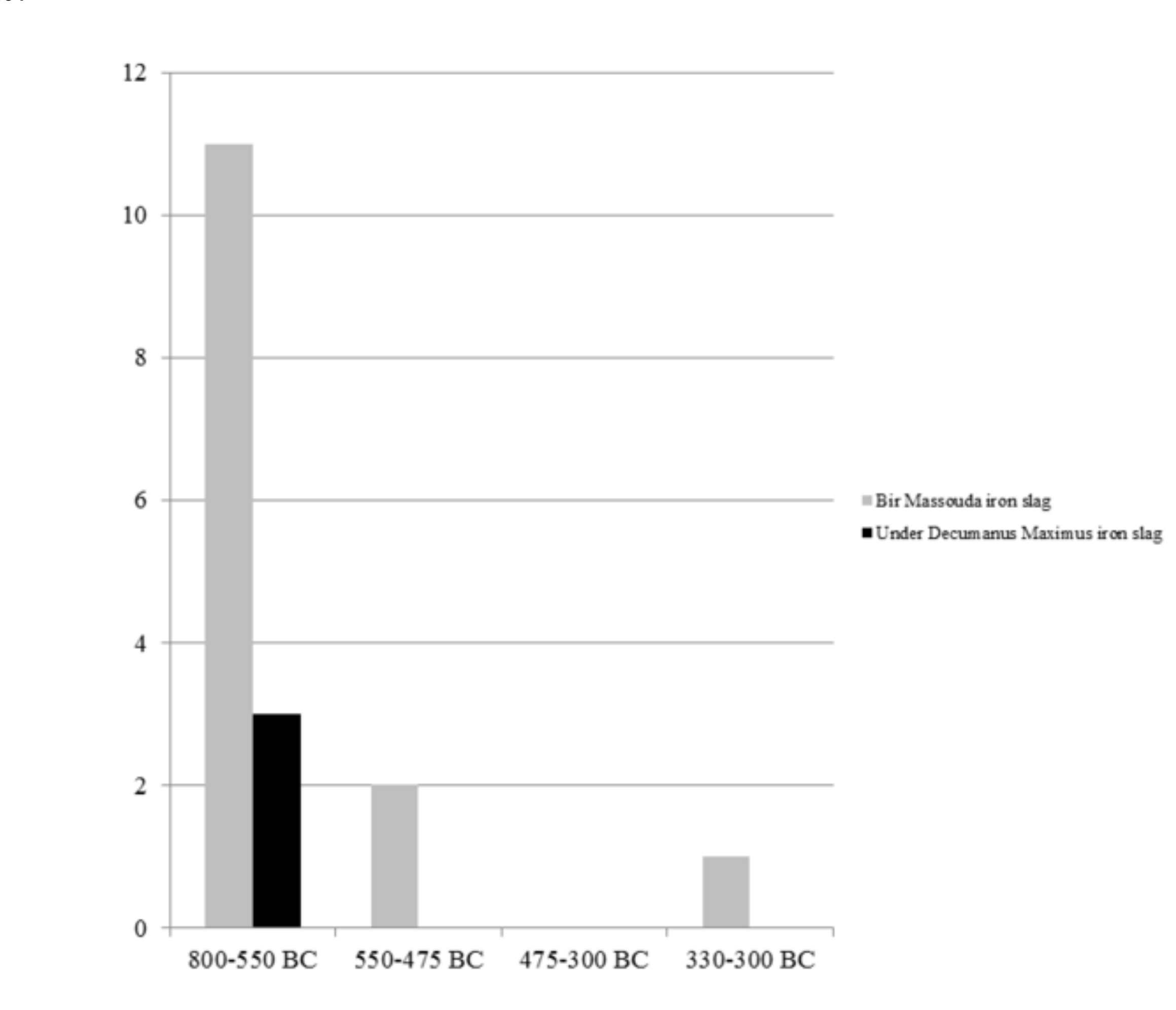

"Bir Masscuda iron slag
-Under Decumanus Maximus ir on slag

- Bir Massouda iron slag
-Under Decumanus Maximus ir cn slag

te

-

-



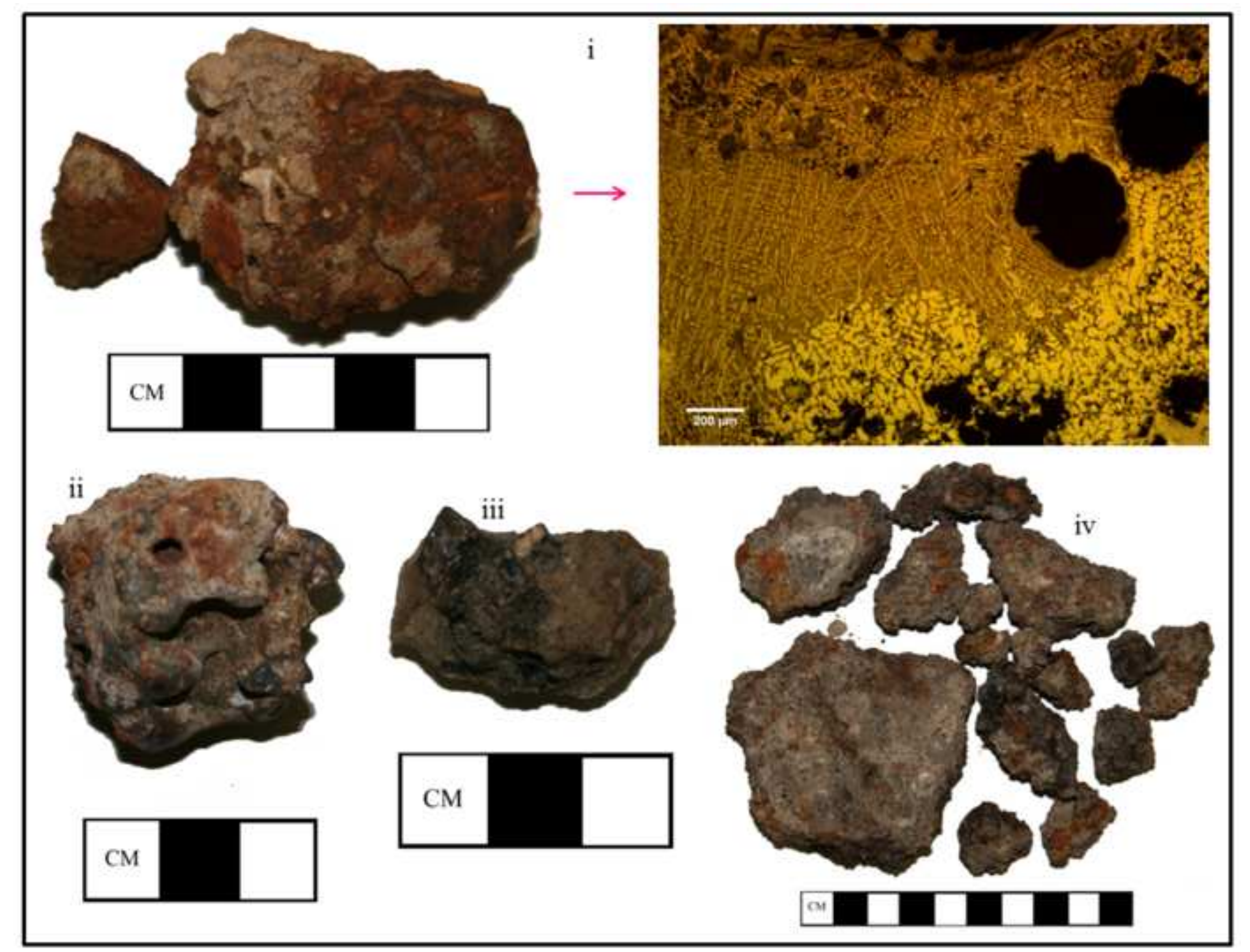

का

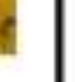

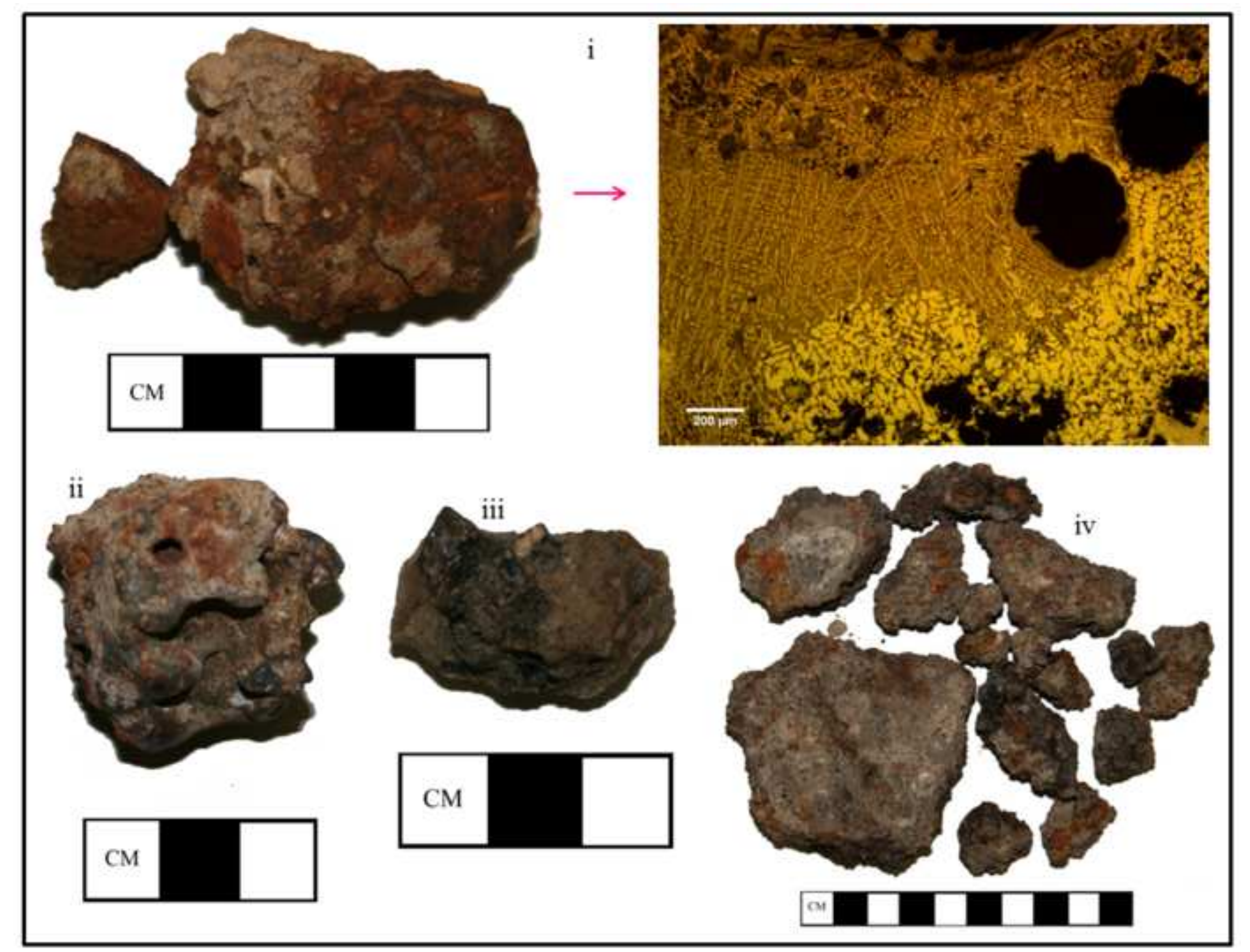




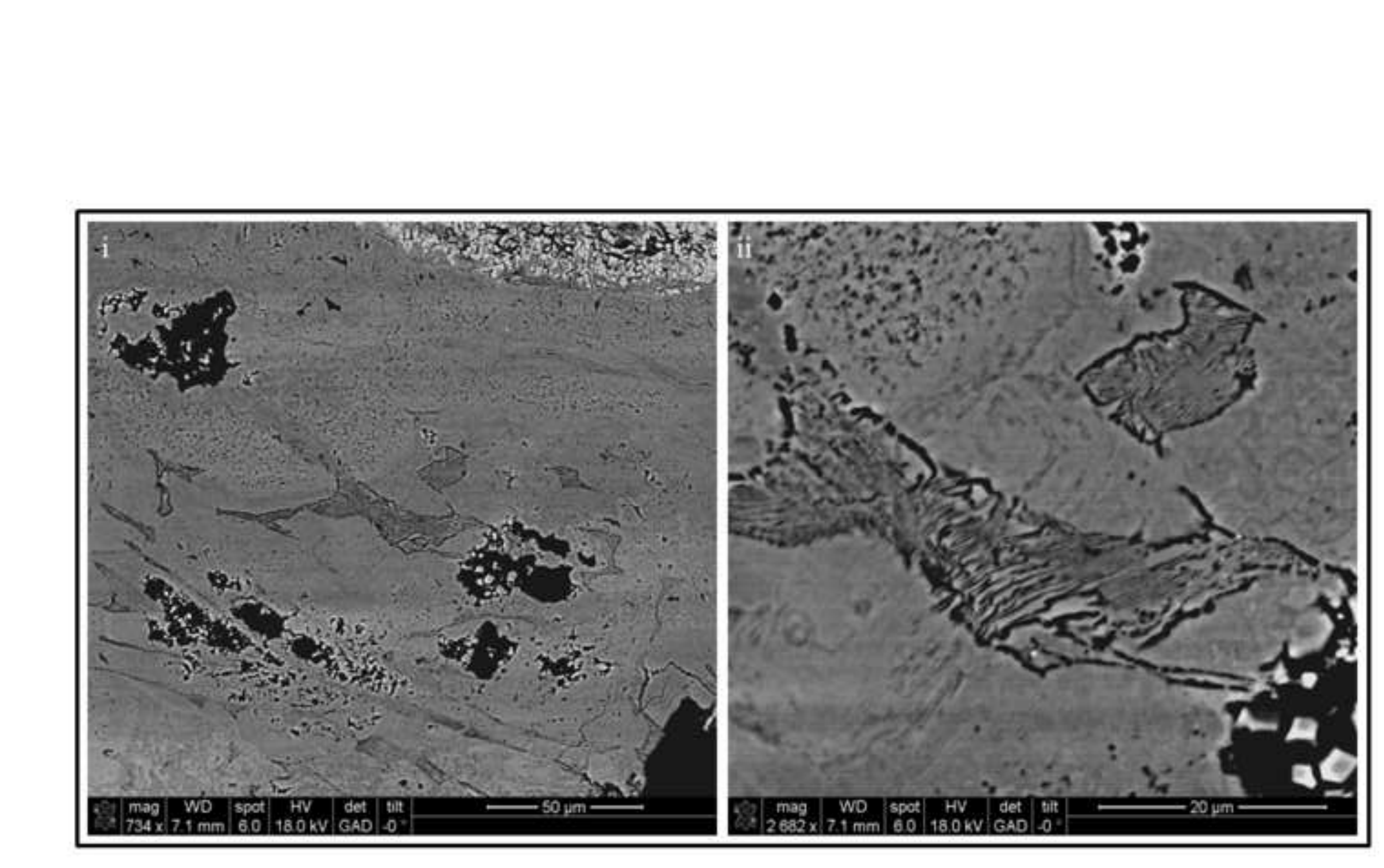




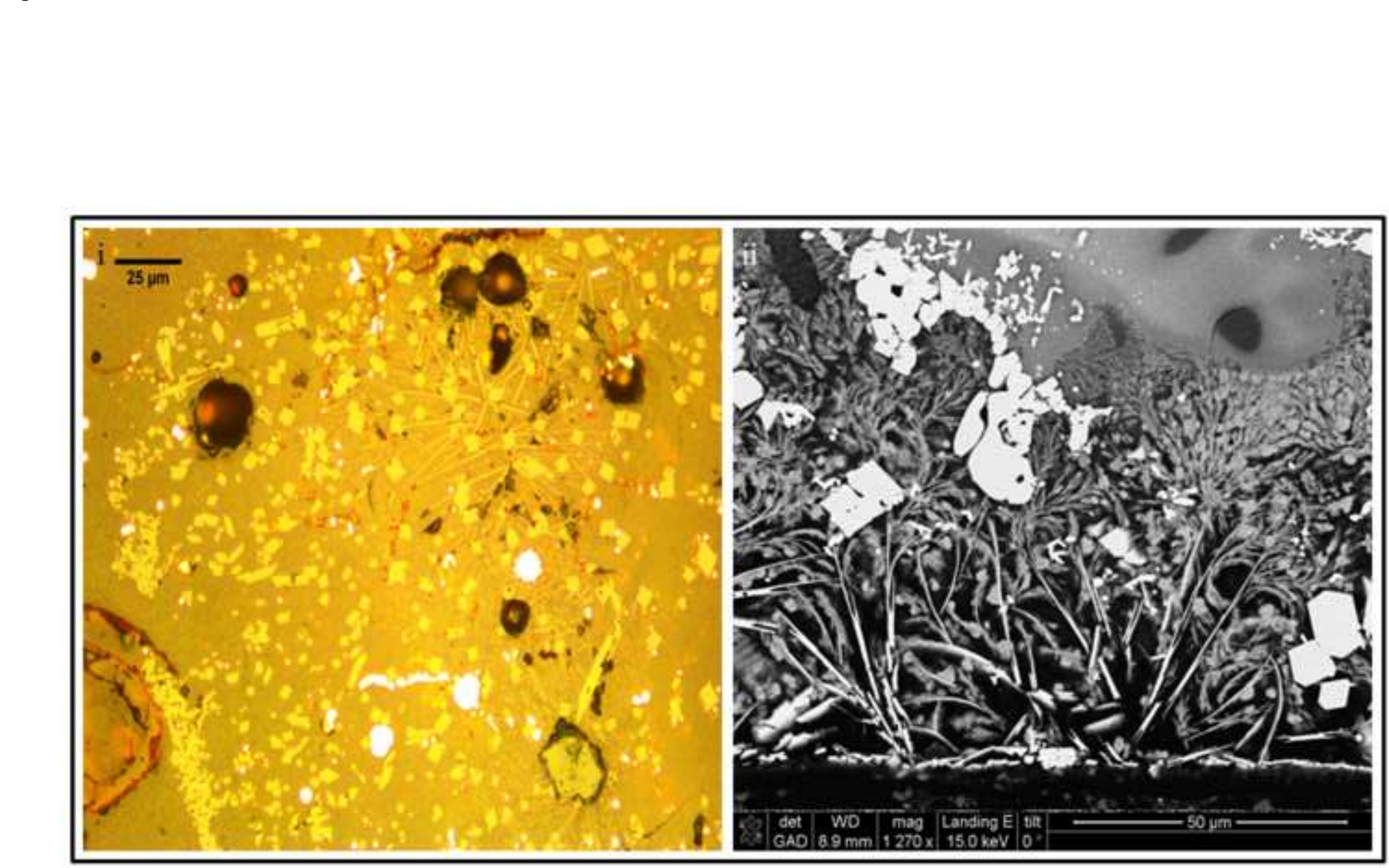



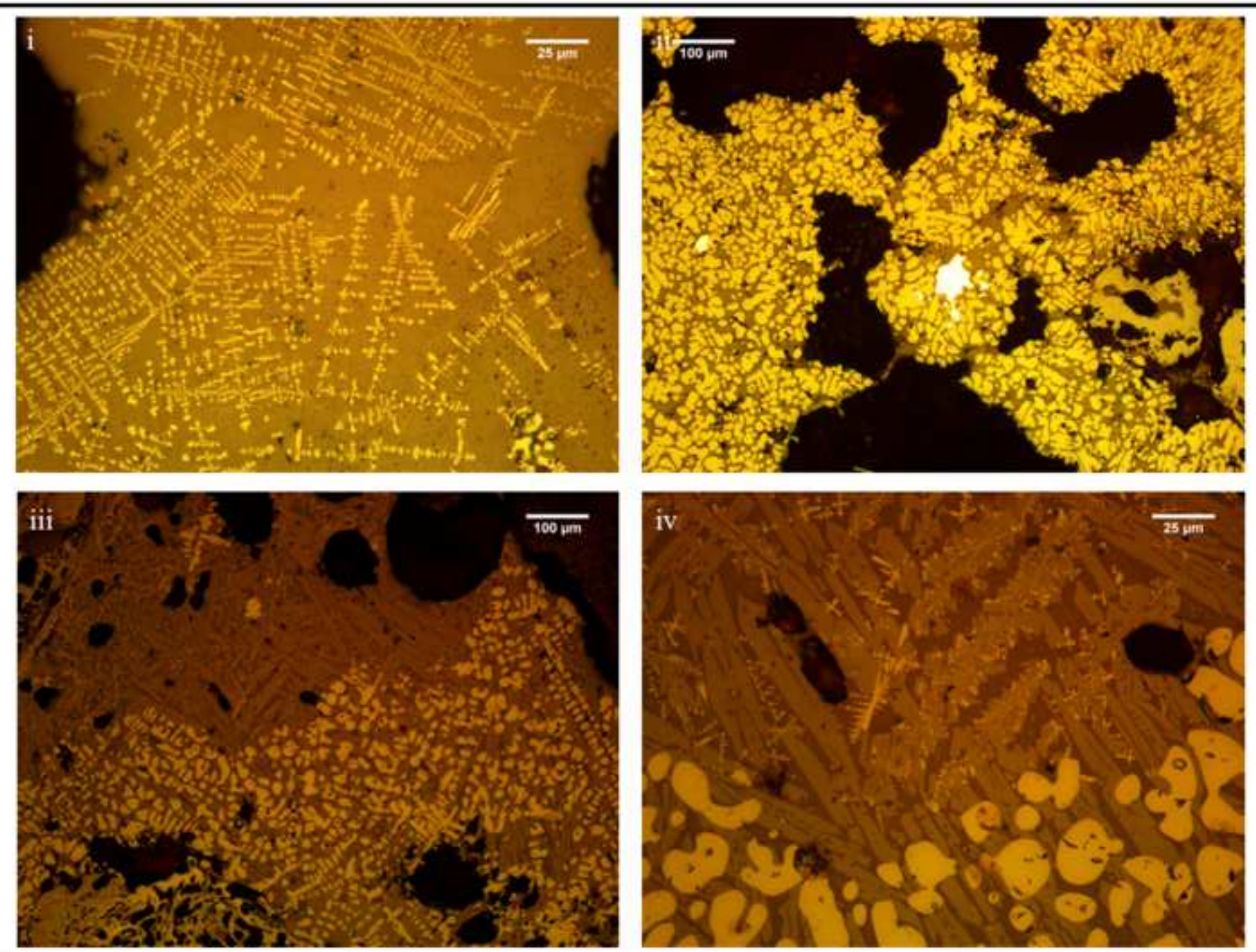

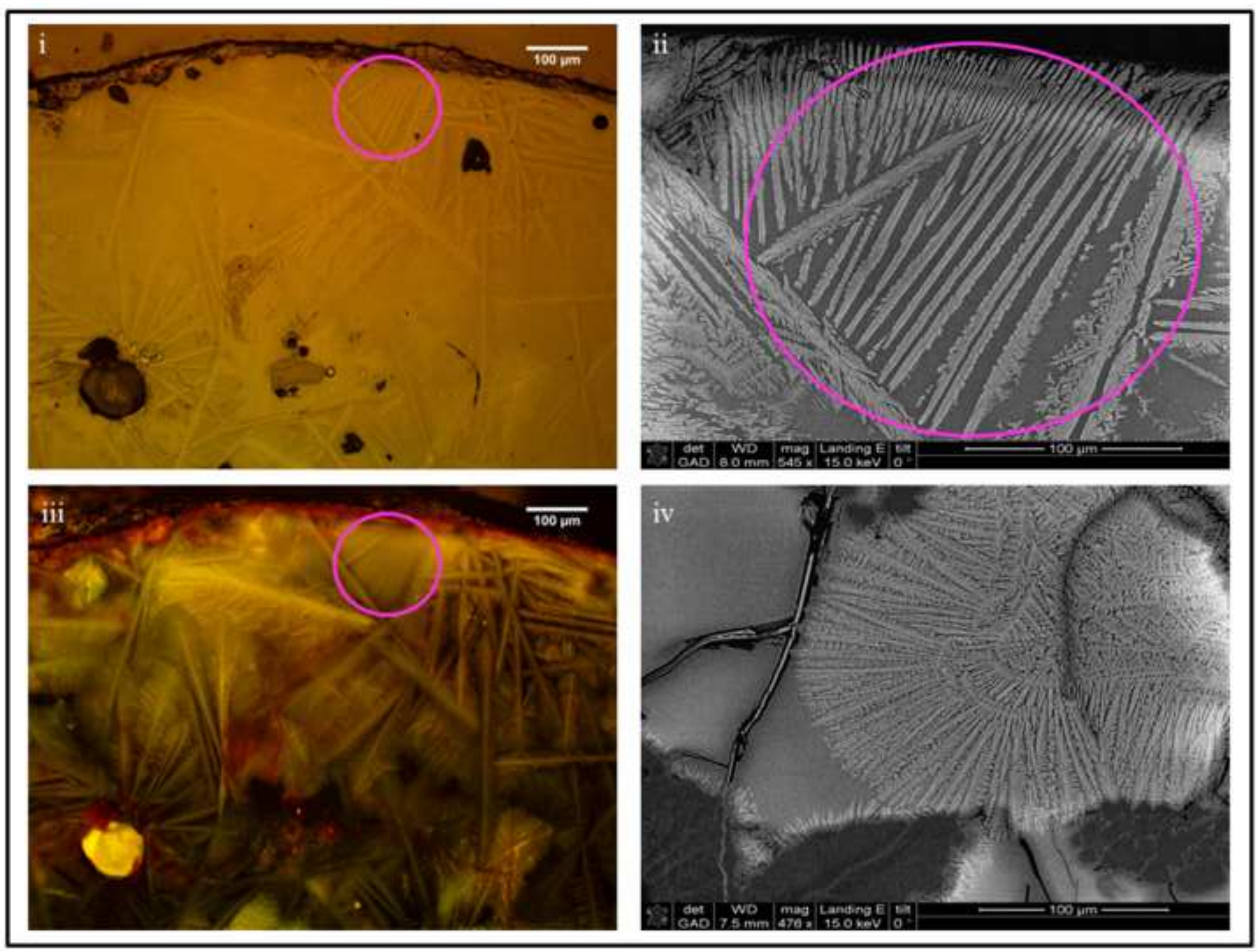

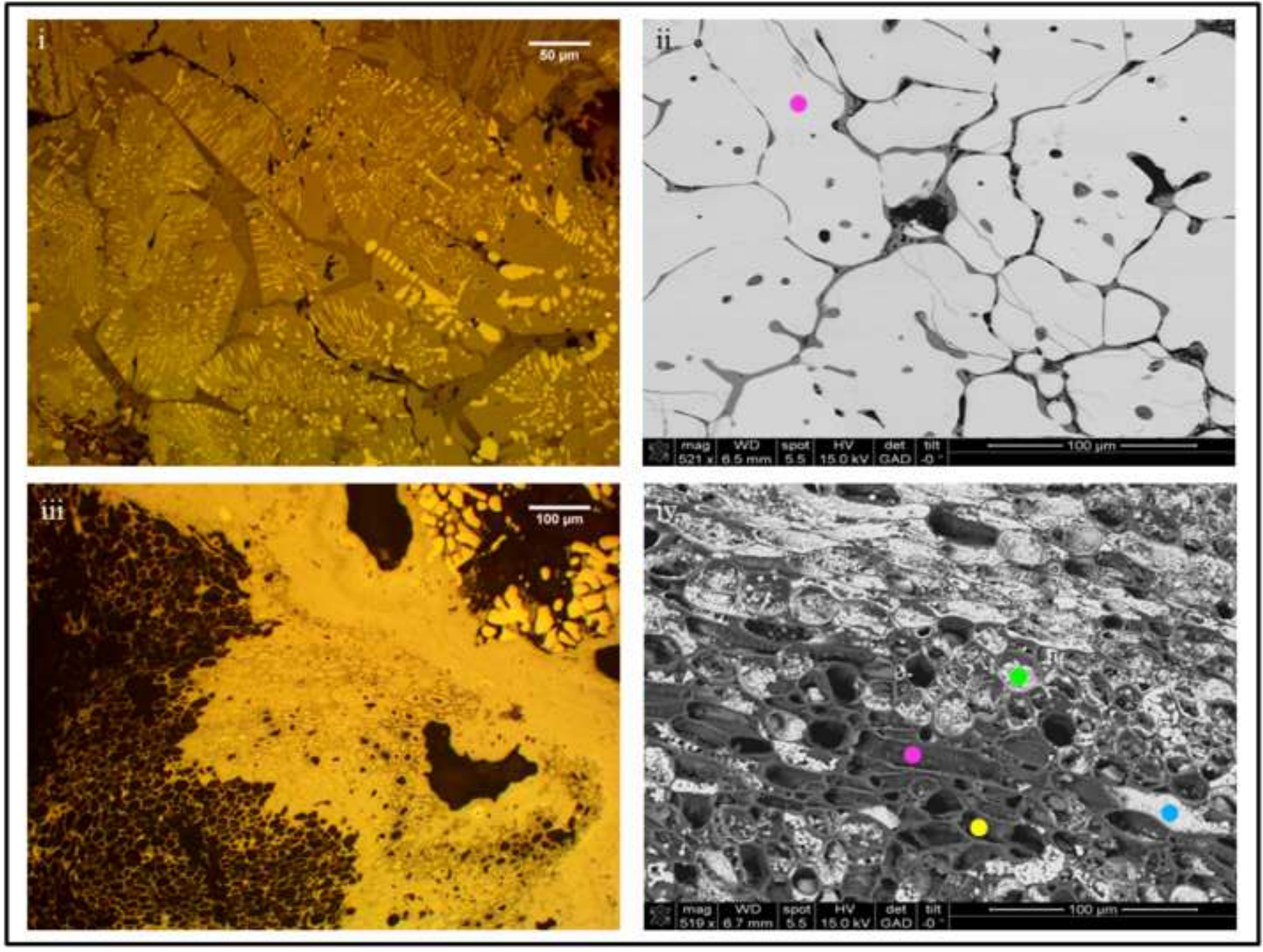